\title{
Legumain Induces Oral Cancer Pain by Biased Agonism of Protease-Activated Receptor-2
}

\author{
Nguyen Huu Tu, ${ }^{1 *}$ Dane D. Jensen, ${ }^{1,2 *}{ }^{\circledR}$ Bethany M. Anderson, ${ }^{3}$ Elyssa Chen, ${ }^{1}$ Nestor N. Jimenez-Vargas, ${ }^{4}$ \\ Nicole N. Scheff, ${ }^{1}$ Kenji Inoue, ${ }^{1}$ Hung D. Tran, ${ }^{1}$ John C. Dolan, ${ }^{1}$ Tamaryn A. Meek, ${ }^{5}$ Morley D. Hollenberg, ${ }^{6}$ \\ Cheng Z. Liu, ${ }^{7}$ Stephen J. Vanner, ${ }^{4}$ Malvin N. Janal, ${ }^{8}$ Nigel W. Bunnett, ${ }^{2}$ Laura E. Edgington-Mitchell, ${ }^{1,3,5 \#}$ and \\ Brian L. Schmidt ${ }^{1 *}$ \\ ${ }^{1}$ Oral and Maxillofacial Surgery, Bluestone Center for Clinical Research, New York University College of Dentistry, New York, NY 10010, ${ }^{2}$ Department of \\ Molecular Pathobiology, New York University College of Dentistry, New York, NY 10010, ${ }^{3}$ Biochemistry and Molecular Biology, Bio21 Institute, \\ University of Melbourne, Parkville, VIC 3010, ${ }^{4}$ Gastrointestinal Diseases Research Unit, Division of Gastroenterology, Queen's University, Kingston, \\ ON K7L 3N6, Canada, ${ }^{5}$ Drug Discovery Biology, Monash Institute of Pharmaceutical Sciences, Monash University, Parkville, VIC 3052, \\ ${ }^{6}$ Inflammation Research Network-Snyder Institute for Chronic Disease, Physiology and Pharmacology Department, and Medicine Department, \\ University of Calgary Cumming School of Medicine, Calgary, AB T2N 4N1, Canada, ${ }^{7}$ Department of Pathology, New York University Langone Health, \\ New York, NY 10016, and ${ }^{8}$ Department of Epidemiology and Health Promotion, New York University College of Dentistry, New York, NY 10010
}

Oral squamous cell carcinoma (OSCC) is one of the most painful cancers, which interferes with orofacial function including talking and eating. We report that legumain (Lgmn) cleaves protease-activated receptor-2 $\left(\mathrm{PAR}_{2}\right)$ in the acidic OSCC microenvironment to cause pain. Lgmn is a cysteine protease of late endosomes and lysosomes that can be secreted; it exhibits maximal activity in acidic environments. The role of Lgmn in $\mathrm{PAR}_{2}$-dependent cancer pain is unknown. We studied Lgmn activation in human oral cancers and oral cancer mouse models. Lgmn was activated in OSCC patient tumors, compared with matched normal oral tissue. After intraplantar, facial or lingual injection, Lgmn evoked nociception in wild-type (WT) female mice but not in female mice lacking $\mathrm{PAR}_{2}$ in $\mathrm{Na}_{V} 1.8$-positive neurons $\left(\mathrm{Par}_{2} \mathrm{Na}_{v} 1.8\right)$, nor in female mice treated with a Lgmn inhibitor, LI-1. Inoculation of an OSCC cell line caused mechanical and thermal hyperalgesia that was reversed by LI-1. $\mathrm{Par}_{2} \mathrm{Na}_{v} 1.8$ and $\mathrm{Lgmn}$ deletion attenuated mechanical allodynia in female mice with carcinogen-induced OSCC. Lgmn caused $\mathrm{PAR}_{2}$-dependent hyperexcitability of trigeminal neurons from WT female mice. $\mathrm{Par}_{2}$ deletion, LI-1, and inhibitors of adenylyl cyclase or protein kinase A (PKA) prevented the effects of Lgmn. Under acidified conditions, Lgmn cleaved within the extracellular $\mathrm{N}$ terminus of $\mathrm{PAR}_{2}$ at $\mathrm{Asn}^{30} \downarrow \mathrm{Arg}^{31}$, proximal to the canonical trypsin activation site. Lgmn activated $\mathrm{PAR}_{2}$ by biased mechanisms in HEK293 cells to induce $\mathrm{Ca}^{2+}$ mobilization, cAMP formation, and PKA/protein kinase D (PKD) activation, but not $\beta$-arrestin recruitment or $\mathrm{PAR}_{2}$ endocytosis. Thus, in the acidified OSCC microenvironment, Lgmn activates $\mathrm{PAR}_{2}$ by biased mechanisms that evoke cancer pain.

Key words: asparaginyl endopeptidase; cancer pain; legumain; oral cancer; protease; protease-activated receptor-2

Significance Statement

Oral squamous cell carcinoma (OSCC) is one of the most painful cancers. We report that legumain (Lgmn), which exhibits maximal activity in acidic environments, cleaves protease-activated receptor-2 $\left(\mathrm{PAR}_{2}\right)$ on neurons to produce OSCC pain. Active Lgmn was elevated in OSCC patient tumors, compared with matched normal oral tissue. Lgmn evokes pain-like behavior through $\mathrm{PAR}_{2}$. Exposure of pain-sensing neurons to Lgmn decreased the current required to generate an action potential through $\mathrm{PAR}_{2}$. Inhibitors of adenylyl cyclase and protein kinase A (PKA) prevented the effects of Lgmn. Lgmn activated PAR to induce calcium mobilization, cAMP formation, and activation of protein kinase D (PKD) and PKA, but not $\beta$-arrestin recruitment or $\mathrm{PAR}_{2}$ endocytosis. Thus, Lgmn is a biased agonist of $\mathrm{PAR}_{2}$ that evokes cancer pain.

Received May 16, 2020; revised 0ct. 22, 2020; accepted 0ct. 23, 2020.

Author contributions: N.H.T., D.D.J., B.M.A., E.C., N.N.J.-V., J.C.D., S.J.V., N.W.B., L.E.E.-M., and B.L.S. designed research; N.H.T., D.D.J., B.M.A., E.C., N.N.J.-V., N.N.S., K.I., H.D.T., T.A.M., M.D.H., C.Z.L., and L.E.E.-M. performed research; N.H.T., D.D.J., B.M.A., E.C., N.N.J.-V., T.A.M., C.Z.L., M.N.J., and L.E.E.-M. analyzed data; N.H.T., D.D.J., E.C., N.N.J.-V., J.C.D., N.W.B., L.E.E.-M., and B.L.S. wrote the paper.

${ }^{*}$ N.H.T. and D.D.J. are first authors.

\#L.E.E.-M. and B.L.S. are senior authors.

This work was supported by National Institutes of Health Grants NS102722, DE026806, DK118971, and DE029951 (to N.W.B., B.L.S.) and the Department of Defense Grant W81XWH1810431 (to N.W.B., B.L.S.). L.E.E.-M. was supported by the Priority-Driven Collaborative Cancer Research Grant GNT1157171 (co-funded by Cancer Australia and Cure (ancer), a Grimwade Fellowship from the Russell and Mab Grimwade Miegunyah Fund at The University of Melbourne, and the Australian Research Council Discovery Early Career Researcher Award Fellowship DE180100418.

N.W.B. is a founding scientist of Endosome Therapeutics Inc, and research in N.W.B.'s laboratory is partly supported by Takeda Pharmaceuticals International. J.C.D. fabricates dolognawmeter assay devices through Gnatheon Scientific LLC. All other authors declare no competing financial interests.

Correspondence should be addressed to Laura E. Edgington-Mitchell at laura.edgingtonmitchell@ unimelb.edu.au or Brian L. Schmidt at bls322@nyu.edu.

https://doi.org/10.1523/JNEUROSCI.1211-20.2020

Copyright $\odot 2021$ the authors 
Table 1. Patient profiles

\begin{tabular}{lllllll}
\hline Patient \# & Sex & Age & Ethnicity & Tumor location & Primary tumor stage & Nodal status \\
\hline 1 & F & 71 & Hispanic & Mandibular gingiva & pT4a & pN0 \\
2 & M & 57 & Hispanic & Mandibular gingiva & pN2a & pT4a \\
3 & M & 66 & Hispanic & Floor of mouth, mandibular gingiva & pT4a & pT1 \\
4 & F & 77 & White/Non-Hispanic & Mandibular gingiva & pT2 & pN0 \\
5 & F & 50 & Asian & Tongue & pN0 & pN0 \\
6 & M & 93 & Asian & Mandibular gingiva & Maxillary gingiva & \\
7 & F & 81 & White/Non-Hispanic & & &
\end{tabular}

\section{Introduction}

Up to $90 \%$ of cancer patients endure pain; oral cancer is one of the most painful (van den Beuken-van Everdingen et al., 2007). Pain often overwhelms oral cancer patients in the final months of life; these patients suffer most while speaking, drinking, or eating, and their quality of life plummets (Connelly and Schmidt, 2004; Kolokythas et al., 2007). Oral squamous cell carcinoma (OSCC) pain worsens with disease progression and responds poorly to opioids. Development of an alternative to opioids is stymied by our poor understanding of the mechanism driving cancer pain. While the etiology of oral cancer pain is not well understood, it is known that OSCC secretes mediators that sensitize and activate nociceptors within the cancer microenvironment and generate pain. These mediators include endothelin, ATP, nerve growth factor, and proteases; proteases produce pain by cleaving protease-activated receptor- $2\left(\mathrm{PAR}_{2}\right)$ on nociceptors (Pickering et al., 2008; Schmidt et al., 2007; Lam and Schmidt, 2010; Ye et al., 2011, 2014b; Lam et al., 2012). The proteases that activate $\mathrm{PAR}_{2}$ in the OSCC microenvironment are unknown. Anaerobic metabolism in tumors and inflamed tissues acidifies extracellular fluid. Legumain (Lgmn; asparaginyl endopeptidase) is a cysteine protease of late endosomes and lysosomes with an acidic $\mathrm{pH}$ optimum. Although Lgmn has been implicated in tumor metastasis (Kembhavi et al., 1993), and patients with metastatic oral cancer report greater pain (Connelly and Schmidt, 2004), it is unknown whether Lgmn causes $\mathrm{PAR}_{2}$-dependent cancer pain.

$\mathrm{PAR}_{2}$ is a G-protein-coupled receptor (GPCR) expressed by nociceptors that mediates neurogenic inflammation and pain (Steinhoff et al., 2000; Vergnolle et al., 2001). Proteases activate $\mathrm{PAR}_{2}$ through distinct mechanisms. The canonical agonists trypsin, tryptase, and kallikrein cleave within the extracellular $\mathrm{N}$ terminus of $\mathrm{PAR}_{2}$, which exposes a tethered ligand that binds to and activates the cleaved receptor (Nystedt et al., 1995; Böhm et al., 1996a; Corvera et al., 1997; Angelo et al., 2006). The biased agonists cathepsin $\mathrm{S}$ and elastase cleave at different sites within the $\mathrm{PAR}_{2} \mathrm{~N}$ terminus, leading to distinct pathways of $\mathrm{PAR}_{2}$ signaling and trafficking (Ramachandran et al., 2009; Zhao et al., 2014). $\mathrm{PAR}_{2}$ couples to signaling pathways that sensitize and activate pain-related ion channels, including the transient receptor potential vanilloid (TRPV1, TRPV4) and ankyrin (TRPA1) channels, yielding sustained sensitization of nociceptors and chronic pain (Amadesi et al., 2006; Dai et al., 2007; Zhao et al., 2015). Since $\mathrm{PAR}_{2}$ is upstream of these pronociceptive channels, blockade of proteases and of $\mathrm{PAR}_{2}$ is advantageous for the management of cancer pain. Therefore, there is a need to identify proteases that remain active in the acidified extracellular millieu of tumors and to determine whether they activate $\mathrm{PAR}_{2}$ to produce pain. Some proteases known to activate $\mathrm{PAR}_{2}$ show diminished activity under acidic conditions (Hachem et al., 2003, 2005). Moreover, proteases are often profiled in diseased tissues by measurement of protein or mRNA, not activity.
Here, we report that Lgmn is a unique activator of $\mathrm{PAR}_{2}$. We found that Lgmn is reproducibly and robustly activated in OSCC patients and mice with OSCC. Under acidified conditions, Lgmn cleaved $\mathrm{PAR}_{2}$ at a distinct site and activated $\mathrm{PAR}_{2}$ by biased mechanisms, leading to hyperexcitability of nociceptors and nociceptive behavior in mice. A Lgmn inhibitor prevented OSCC pain in mice. Thus, we have identified Lgmn as a novel mediator and therapeutic target for OSCC pain.

\section{Materials and Methods}

Reagents. We used recombinant human Lgmn $(440,000 \mathrm{ng} / \mathrm{ml}$, catalog \#2199-CY-010, R \& D System), Lgmn substrate Z-Ala-Ala-Asn-AMC (I-1865; Bachem), DMEM and HBSS (ThermoFisher), $\mathrm{PAR}_{2}$ agonist 2Furoyl-LIGRLO- $\mathrm{NH}_{2}$ and $\mathrm{PAR}_{1}$ agonist TFLLR-NH $\mathrm{N}_{2}$ (Tocris), Lgmngenerated $\mathrm{PAR}_{2}$ activating peptide (RSSKGR; GL Biochem), and other reagents (Sigma) unless otherwise specified.

Lgmn activation and inhibition. Lgmn was activated per manufacturer protocol. Lgmn activation was confirmed by incubating Lgmn $(1 \mathrm{ng} / \mu \mathrm{l})$ with Z-Ala-Ala-Asn-AMC $(200 \mu \mathrm{M})$ in dilution buffer [ $250 \mathrm{~mm}$ $\mathrm{NaCl}, 50 \mathrm{~mm}$ 2-(N-morpholino) ethanesulfonic acid (MES); $\mathrm{pH}$ 5.0] or MES-HBSS (HBSS, 50 mm MES pH 5.0, 5.5 or 6.0). Fluorescence (excitation $340 \mathrm{~nm}$, emission $460 \mathrm{~nm}$ ) was measured every $30 \mathrm{~s}$ for $10 \mathrm{~min}$ in a Flexstation three plate reader (Molecular Devices). Lgmn ( $1 \mathrm{ng} / \mu \mathrm{l})$ was assayed for activity in the presence of the Lgmn inhibitors QDD100531 or QDD123427 (1 pM $-10 \mu \mathrm{M})$ and $\mathrm{PAR}_{2}$ antagonists I-343 $(10 \mu \mathrm{M})$ or GB88 (10 $\mu \mathrm{M}$; Farmer, 2013; Lieu et al., 2016; Jimenez-Vargas et al., 2018). Rich Williams provided the Lgmn inhibitors. The specificity of QDD100531 was demonstrated in Ness et al. 2015 (compound 9h in Supplementary Table 1); QDD100531 showed no reactivity to other proteases including cathepsin S, cathepsin B, caspase-3, caspase-8, or USP17 (Ness et al., 2015). QDD123427 showed similar specificity (R. Williams, personal communication). GB88 exhibited specific antagonist activity against four $\mathrm{PAR}_{2}$ agonists differing in structure and mechanism; selectivity of GB88 for $\mathrm{PAR}_{2}$ over $\mathrm{PAR}_{1}$ and $\mathrm{PAR}_{4}$ was also demonstrated (Suen et al., 2012). I-343, a member of the I-191 family of full $\mathrm{PAR}_{2}$ antagonists, inhibited inositol phosphate-1 $\left(\mathrm{IP}_{1}\right)$ generation induced by the $\mathrm{PAR}_{2}$ agonists trypsin and 2-Furoyl-LIGRLO-NH${ }_{2}$, but not $\mathrm{IP}_{1}$ accumulation induced by ATP (Farmer, 2013; Jiang et al., 2018; JimenezVargas et al., 2018). For studies in mice, activated Lgmn was diluted in $50 \mathrm{~mm}$ MES and $250 \mathrm{~mm} \mathrm{NaCl}$, at pH 5.0 (dilution buffer) to a concentration of $300 \mathrm{ng} / 20 \mu \mathrm{l}$. For the in vivo experiments with LI-1 (10 mM, $100 \mu \mathrm{l}$, diluted in DMSO; Lee and Bogyo, 2010) the inhibitor was injected into the tail vein $2 \mathrm{~h}$ before injection of Lgmn. LI- 1 was a gift from Matthew Bogyo. It is a covalent Lgmn inhibitor that exhibits $>20,000$-fold selectivity for Lgmn over cathepsin B, cathepsin L, and caspase-3. It has previously been shown to inhibit all Lgmn activity in vivo within $1 \mathrm{~h}$ of administration (Edgington-Mitchell et al., 2016).

OSCC patients. Patients were screened and enrolled through New York University (NYU) Oral Cancer Center after consent. Detailed demographic information (age, sex, ethnicity, cancer location, primary tumor stage, and evidence of metastasis) was collected. During surgical resection, tumor and matched normal oral mucosa specimens were collected (normal was harvested at anatomically matched contralateral site). Specimens were frozen in liquid nitrogen and maintained at $-80^{\circ} \mathrm{C}$. The 
Committee on Human Research at NYU Langone Medical Center approved human studies.

Mice. Female C57BL/6J (\#000664) and NU/J Foxn1 ${ }^{\text {nu }}$ athymic mice (\#002019), four to eightweeks, were from The Jackson Laboratory. Female C57BL/6J and F2rl1 ${ }^{-l-}$ (B6. Cg-F2rll $\left.{ }^{t m 1 M s l b} / \mathrm{J}\right)$ mice (\#004993), four to eight weeks, from The Jackson Laboratory, were used for trigeminal ganglia (TG) dissociation. F2rl1 conditional knock-out (KO) C57BL/ 6 mice were generated by genOway as described (Jimenez-Vargas et al., 2018). $\mathrm{Lgmn}^{-1-}$ C57BL/6N mice were a gift from Thomas Reinheckel (Matthews et al., 2010). The NYU Institutional Animal Care and Use Committee approved mouse studies.

Analysis of total and active Lgmn in tissues. Snap frozen human and murine tissues were sonicated in $50 \mathrm{~mm}$ citrate $\mathrm{pH}$ 5.5, 0.5\% CHAPS, $0.1 \%$ Triton X-100, and $4 \mathrm{~mm}$ DTT ( $10 \mu \mathrm{l} / \mathrm{mg}$ tissue). Solids were cleared by centrifugation and protein concentration was measured by BCA assay (Pierce). Protein was diluted in citrate buffer $(50 \mu \mathrm{g} / 20 \mu \mathrm{l}$ buffer), and LE2 8 was added from a $100 \times$ DMSO stock ( $1 \mu \mathrm{M}$ final; Edgington et al., 2013). Samples were incubated at $37^{\circ} \mathrm{C}$ for $15 \mathrm{~min}$, and the reaction was quenched with $5 \times$ sample buffer [ $200 \mathrm{~mm}$ Tris- $\mathrm{Cl}$ ( $\mathrm{pH}$ 6.8), $8 \%$ SDS, $0.04 \%$ bromophenol blue, $5 \% \beta$-mercaptoethanol, and $40 \%$ glycerol]. Protein was resolved on a $15 \%$ polyacrylamide gel under reducing conditions. LE28 binding was detected by scanning the gel for Cy5 fluorescence using a Typhoon 5 (GE Healthcare). Proteins were transferred to nitrocellulose membranes for immunoblotting with a goat anti-human Lgmn antibody (R \& D AF2199, 1:1000 diluted in 50\% Li-Cor blocking buffer and 50\% PBS-T containing 0.05\% Tween 20). Donkey-anti goatHRP (1:10,000; A15999; Invitrogen) was used for detection with Clarity Western ECL Substrate (Bio-Rad). Actin (Sigma A5060) and ponceau stain were controls.

Tongue xenograft cancer model. An orthotopic xenograft tongue cancer model was created by injecting HSC-3 into the tongue (Lam et al., 2012). NU/J Foxn1 $1^{n u}$ athymic mice were injected in the left lateral tongue under anesthesia $\left[1 \times 10^{5}\right.$ HSC- 3 human tongue OSCC cells suspended in $20 \mu \mathrm{l}$ vehicle (1:1 mixture of DMEM and Matrigel; Corning, reference \#354234), or vehicle alone]. After two weeks, the resulting xenografted tumors and vehicle-injected tongues were excised and snap frozen for protein analysis as above. Goat anti-mouse Lgmn (R \& D AF2058) and donkey anti-goat IR-800 (Li-Cor) were used in the immunoblot.

Paw xenograft cancer model. The plantar surface of the right hind paw of NU/J Foxn $1^{n u}$ athymic mice were inoculated with $1 \times 10^{5}$ HSC-3 in $20 \mu \mathrm{l}$ of DMEM and Matrigel (Ye et al., 2011, 2014a). The paw xenograft model permits measurement of mechanical and heat hypersensitivity of the paw. By $14 \mathrm{~d}$ after inoculation, a visible tumor developed in the paw. After measuring baseline mechanical and thermal withdrawal thresholds, HSC-3 were inoculated into the hind paw. Mechanical and thermal withdrawal were measured at post inoculation days $3,6,10$, and 13. On post inoculation day 14 , LI-1 $(10 \mathrm{~mm}, 100 \mu \mathrm{l})$ was injected into the tail vein. Mechanical and thermal withdrawal were measured at 1, 3, $6,12,24$, and $48 \mathrm{~h}$ after injection of LI-1 into the paw cancer mouse model.

4-Nitroquinoline 1-oxide (4NQO)-induced OSCC model. An OSCC mouse model was generated by exposing mice to 4 NQO $(100 \mu \mathrm{g} / \mathrm{ml})$ in drinking water for 16 weeks (Lam et al., 2012). Functional allodynia (gnaw-time) was measured with dolognawmeters (Dolan et al., 2010). Before administration of $4 \mathrm{NQO}$, mice were examined to confirm the absence of oral abnormalities. $4 \mathrm{NQO}$ administration and dolognawmeter training over 15 sessions overlapped; baseline gnaw-time was calculated from the final 5 sessions. Functional allodynia was measured after 28 weeks. The tongue was harvested and a 1- to 2-mm coronal section was dissected from the most clinically suspicious region, fixed in $10 \%$ neutral buffer formalin, and processed for paraffin embedding and slide preparation. Four 5- $\mu \mathrm{m}$ hematoxylin and eosin ( $\mathrm{H} \& \mathrm{E}$ )-stained tongue sections were evaluated for OSCC. Two pathologists blinded to group identity performed histopathologic analysis. Only mice with histologically confirmed OSCC were included in the analysis of nociception.

Mechanical and thermal nociception in the hind paw. To assess mechanical nociception, mice were placed on a platform with a metal mesh floor and acclimated for $1 \mathrm{~h}$. Paw withdrawal threshold was measured with von Frey filaments (Stoelting; Pickering et al., 2008). Withdrawal threshold was defined as the gram-force sufficient to elicit left hindpaw withdrawal. Withdrawal threshold for each animal was determined as the mean of three trials for each animal. Thermal hyperalgesia was measured with a paw thermal stimulator (IITC Life Sciences; Yamano et al., 2017). Mice were placed in a plastic chamber on a $25^{\circ} \mathrm{C}$ glass surface. $\mathrm{A}$ radiant heat source was focused on the left hind paw and withdrawal latency was measured as the mean of three trials taken at least 5 min apart in each mouse. The cutoff latency was established at $20 \mathrm{~s}$. Lgmn (300 ng in $20 \mu \mathrm{l}$ ) or vehicle (control in $20 \mu \mathrm{l}$ ) was administered by intraplantar injection into the left hind paw under $1 \%$ isoflurane. Injections were made $1 \mathrm{~h}$ before the withdrawal tests (days 0,1 , and 4 ).

Facial mechanical nociception. Mice were placed individually in a transparent, mesh-floor, box and acclimated for $1 \mathrm{~h}$ every other day for two weeks. We measured withdrawal responses to mechanical stimulation of the left cheek with von Frey filaments ranging from 0.008 to $4 \mathrm{~g}$ force (11 filaments in total) in ascending order (Deseure et al., 2003). We applied the von Frey filament to the cheek, defined by the area below the eye, between the nose and the ear. Each fiber was applied once; however, if the response to a von Frey filament was equivocal or the mouse was moving, the same von Frey filament was reapplied to the same area of the cheek $10 \mathrm{~s}$ after the first stimulus, or when the mouse stopped moving. The interval between applications of von Frey filaments of different intensities was $5 \mathrm{~min}$. The facial nociception score was reported as a numerical average of the 11 responses in the following response categories: 0: no response; 1 : detection, the mouse is aware of the filament that stimulates the face; the mouse turns its head slightly to the object; 2 : reaction, the mouse turn its head away quickly, pulls it backward or reacts with a single face wipe; 3: escape/attack, the mouse quickly escapes from the object, attacks the object with its paw or mouth, or reacts with two facial swipes; 4 : multiple facial grooming, the mouse responds to the filament simulation with more than three facial wipes continuously. Hair on the left cheek was removed before subcutaneous injections of Lgmn. The whiskers were not trimmed. Lgmn (300 ng in $20 \mu \mathrm{l}$ ) was injected subcutaneously to the left cheek under $1 \%$ isoflurane. Injections were made $1 \mathrm{~h}$ before the facial mechanical withdrawal test at days 0,1 , and 4 .

Orofacial behavior. The dolognawmeter quantifies a behavioral index of orofacial nociception (Dolan et al., 2010). The device measures the time taken to gnaw through a dowel and is a validated index of orofacial nociception in mice with OSCC. Mice were trained for 15 training sessions in the dolognawmeter or until the coefficient of variance of the time required to gnaw was below 0.2. A baseline gnaw-time (mean of the final five training sessions) was established for each mouse. After baseline gnaw-times were determined, treatment or drug injections were initiated and the mice underwent behavioral testing. Each response was analyzed relative to the mouse's baseline. Activated Lgmn, $300 \mathrm{ng}$ in $20 \mu \mathrm{l}$, was injected into the tongue under isoflurane. The injection was performed at days 0,1 , and 4 . One hour after injection, the mice were tested with a dolognawmeter.

Quantification of Lgmn in OSCC cells. Lgmn was measured in HSC-3 and DOK cells by ELISA. HSC- 3 or DOK cells $(\sim 5000 /$ well of a 12 -well plate) were cultured for $72 \mathrm{~h}$ ( $\sim 70 \%$ confluency; Lam et al., 2012). Medium was removed, cells were washed with $5 \mathrm{ml} \mathrm{PBS}$ without $\mathrm{Ca}^{2+}$ and $\mathrm{Mg}^{2+}$, and DMEM $(500 \mu \mathrm{l})$ was added to each well. After $48 \mathrm{~h}$, medium was collected and centrifuged $\left(1500 \mathrm{rpm}, 4 \mathrm{~min}, 4^{\circ} \mathrm{C}\right)$. Cells were homogenized with $100 \mu \mathrm{l}$ of RIPA buffer/well (Thermo Scientific, product \#89901). Cell lysate was collected and centrifuged (1500 rpm, $10 \mathrm{~min}$, $\left.4^{\circ} \mathrm{C}\right)$. The pellet was discarded. A RayBio Human Lgmn ELISA kit (RayBiotech, code ELH-Lgmn-1) was used for Lgmn quantification. The standard curve was generated using the following concentrations: 7000, $2800,1120,448,179,72,29$, and $0 \mathrm{pg} / \mathrm{ml}$ of Lgmn provided with the kit. The optical densities of the standards and samples were read at $450 \mathrm{~nm}$ wavelength using a Promega GloMax luminometer (Promega BioSystems, Model E9032). Alternatively, cells were live-labeled with LE28 ( $1 \mu \mathrm{M}, 0.1 \%$ DMSO) for $4 \mathrm{~h}$, lysed on ice in PBS containing $0.1 \%$ Triton X-100, and cleared by centrifugation. Supernatants collected overnight in serum-free media were concentrated using an Amicon Filter with a 3-kDa cutoff. Total 
protein from whole-cell lysates or supernatants $(\sim 60 \mu \mathrm{g})$ were resolved by SDS-PAGE. Gels were scanned for Cy5 fluorescence and subject to Lgmn immunoblotting.

Lgmn immunofluorescence in cancer cells. HSC-3 and DOK cells were grown on cover slips at $37^{\circ} \mathrm{C}, 5 \% \mathrm{CO}_{2}$ for $48 \mathrm{~h}$. Cells were washed with PBS and fixed in $4 \%$ paraformaldehyde at room temperature for $15 \mathrm{~min}$. Cells were incubated with $3 \%$ bovine serum albumin (BSA) in PBS to block non-specific binding, then incubated with mouse monoclonal anti-Lgmn antibody (Santa Cruz Biotechnology, B-8: sc-133234, lot \#A0610), $1: 50,4^{\circ} \mathrm{C}$, overnight. Cells were washed in PBS and then incubated with goat antimouse secondary antibody conjugated to Alexa Fluor 488 (Life Technology, A11029), 1:300, room temperature for $3.5 \mathrm{~h}$. Nuclei were stained with Hoechst (Thermo Scientific, product \#62249, lot \#RG2244203). The cover slips were mounted on slides in Fluoromount G (Electron Microscope Sciences). A laser scanning confocal microscope (LSM 700, Carl Zeiss) was used to obtain fluorescent images. The images were captured with a Zeiss Plan-Apochromat $63 \times 1$ 1.40 Oil DIC M27 objective lens for Lgmn signal quantification or $20 \times$ DIC objective lens for capturing the representative images. The fluorescent signal intensity of each cell was measured by a blinded researcher using NIH ImageJ. Controls included the following: (1) staining of the spleen from wild-type (WT) and $\mathrm{Lgmn}^{-1-}$ mice; (2) preabsorption of the primary anti-Lgmn antibody with Lgmn; and (3) omission of the primary antibody. For the preabsorption negative control, the primary anti-Lgmn antibody ( $0.07 \mathrm{~nm}$, equivalent to 1:50 dilution) was incubated in $10 \times$ higher concentration of activated Lgmn (0.7 nM) at $37^{\circ} \mathrm{C}$ for $48 \mathrm{~h}$ versus cells stained with the primary anti-Lgmn antibody, which was incubated in activated Lgmn vehicle. WT and $\mathrm{Lgmn}^{-1-}$ mice were anesthetized with $100 \mathrm{mg} / \mathrm{kg}$ ketamine and $10 \mathrm{mg} / \mathrm{kg}$ xylazine (intraperitoneal) and transcardially perfused with $25 \mathrm{ml}$ cold PBS, followed by $25 \mathrm{ml}$ of $10 \%$ neutral formalin solution. The spleen was postfixed in $10 \%$ neutral formalin solution for $24 \mathrm{~h}$, cryoprotected in $30 \%(\mathrm{v} / \mathrm{v})$ sucrose in PBS for $2 \mathrm{~d}$ at $4^{\circ} \mathrm{C}$, and embedded in Tissue-Tek ${ }^{\mathrm{R}}$ optimum cutting temperature (OCT) compound (Sakura Finetek). Sections $(10 \mu \mathrm{m})$ were processed for immunofluorescence staining.

Dissociation of TG neurons. Mice were anesthetized with isoflurane, bilateral TG were removed and neurons were enzymatically dispersed as described (Ono et al., 2015). Ganglia were cut into 8-10 segments and incubated for $30 \mathrm{~min}$ in collagenase and dispase (12 mg collagenase, $14 \mathrm{mg}$ dispase in $3 \mathrm{ml} \mathrm{HBSS}$ ). Neurons were triturated and plated onto laminin/poly-L-ornithine-coated coverslips. Neurons were cultured in Leibovitz medium containing $10 \%$ fetal calf serum, with penicillin and streptomycin for $24 \mathrm{~h}\left(37^{\circ} \mathrm{C}, 5 \% \mathrm{CO}_{2}\right)$.

Electrophysiological recording. Hyperexcitability of small TG neurons $(\leq 20 \mu \mathrm{m},<30 \mathrm{pF})$ was quantified by measuring rheobase (Scheff et al., 2018). Whole-cell patch-clamp recordings were made using Axon patch 200B amplifier (Molecular Devices). Digidata 1440A (Molecular Devices) was used for data acquisition and pulse generation. Rheobase was measured using $250 \mathrm{~ms}$ square pulses starting from $-10 \mathrm{pA}$ with steps of $10 \mathrm{pA}$ until the action potential threshold was reached. The resting membrane potentials were recorded at stable conditions without current injection. Neurons with resting membrane potentials more positive than $-40 \mathrm{mV}$ were excluded from analysis. Input resistance was estimated from current-clamp recordings of the voltage response to $250 \mathrm{~ms}$ of $10 \mathrm{pA}$ hyperpolarizing current. Pipette resistance was $4-5 \mathrm{~m} \Omega$ in the following external solution: $140 \mathrm{~mm} \mathrm{NaCl}, 5 \mathrm{~mm} \mathrm{KCl}, 10 \mathrm{~mm}$ HEPES, 10 mM glucose, $1 \mathrm{~mm} \mathrm{MgCl}_{2}$, and $2 \mathrm{mM} \mathrm{CaCl}_{2}$; $\mathrm{pH}$ was adjusted to 7.3-7.4 with $\mathrm{NaOH}$. Pipette solution consisted of the following: $110 \mathrm{~mm}$ K-gluconate, $30 \mathrm{~mm} \mathrm{KCl}, 10 \mathrm{~mm}$ HEPES, $1 \mathrm{~mm} \mathrm{MgCl}_{2}$, and $2 \mathrm{~mm} \mathrm{CaCl} 2 ; \mathrm{pH}$ was adjusted to 7.25 with $\mathrm{KOH}$. Rheobase was measured after $10 \mathrm{~min}$ incubation with Lgmn $(20 \mathrm{ng} / \mathrm{ml}$ in external solution, $\mathrm{pH} 5.5)$, Lgmn $(20 \mathrm{ng} / \mathrm{ml})$ plus LI- $1(10 \mu \mathrm{M})$, or Lgmn vehicle (Lgmn activation buffer pH 5.5). To study the signaling pathways of Lgmn induced hyperexcitability, perforated patch-clamp was performed to avoid dialysis of cytoplasmic constituents. Amphotericin B $(240 \mu \mathrm{g} / \mathrm{ml})$ was used in the pipette solution. Neurons were preincubated with GF109203X (GFX, Tocris) or PKI-tide (both $1 \mu \mathrm{M}, 30 \mathrm{~min}, 37^{\circ} \mathrm{C}$ ) before challenge with Lgmn $(20 \mathrm{ng} / \mathrm{ml})$ or Lgmn vehicle. Rheobase was measured $10 \mathrm{~min}$ after incubation with Lgmn or vehicle.

Cell lines. Human embryonic kidney (HEK293) cells stably expressing the human (h)PAR $\mathrm{PA}_{2}$ with extracellular N-terminal FLAG and intracellular C-terminal HA11 epitopes (HEK-FLAG-PAR 2 -HA cells) have been described (Böhm et al., 1996b). $\mathrm{PAR}_{1}$ and $\mathrm{PAR}_{2}$ were deleted from 
HEK293 cells using CRISPR/Cas9 (Ungefroren et al., 2017). Cells were maintained in DMEM with $10 \%$ fetal bovine serum and hygromycin $\left(100 \mu \mathrm{g} / \mathrm{ml}, 5 \% \mathrm{CO}_{2}, 37^{\circ} \mathrm{C}\right)$. Dysplastic oral keratinocyte, DOK, cell number 94122104 from Sigma-Aldrich was cultured in DMEM/F12 (Invitrogen), 10\% fetal bovine serum, $50 \mathrm{IU} / \mathrm{ml}$ penicillin/streptomycin and $5 \mu \mathrm{g} / \mathrm{ml}$ hydrocortisone. Human OSCC, HSC-3, cell number JCRB0623, was from Japanese Collection of Research Bioresources Cell Bank. HSC-3 was cultured in DMEM, $10 \%$ fetal bovine serum, and $50 \mathrm{IU} / \mathrm{ml}$ penicillin/streptomycin. DOK and HSC-3 cell lines were maintained at $37^{\circ} \mathrm{C}$ with $5 \% \mathrm{CO}_{2}$.

$\mathrm{PAR}_{2}$ cleavage. A peptide corresponding to $\mathrm{hPAR}_{2}$ amino acids 2150 was synthesized by American Peptide Company and dissolved in water at $300 \mu \mathrm{M}$. The peptide was diluted to $200 \mu \mathrm{m}$ with Lgmn activation buffer (50 mu sodium acetate, $100 \mathrm{~mm} \mathrm{NaCl}, \mathrm{pH} 4.5$ ) in the presence and absence of Lgmn ( $200 \mathrm{~nm}$; final volume $25 \mu \mathrm{l})$. After overnight incubation at $37^{\circ} \mathrm{C}$, the reactions were quenched with $25 \mu \mathrm{l}$ of $50 \%$ acetonitrile containing $0.1 \%$ trifluoroacetic acid (TFA). Samples $(2 \mu \mathrm{l})$ were subject to LCMS analysis with a Shimadzu LCMS 2020 fitted with a Phenomenex Luna $3 \mu \mathrm{m} \mathrm{C} 8(2)$ column $(100 \AA, 100 \times 2 \mathrm{~mm})$. A gradient of $0 \%-60 \%$ acetonitrile over $10 \mathrm{~min}$ with $0.05 \%$ TFA was used for separation.

Immunofluorescence in HEK cells. HEK-FLAG-PAR 2 -HA cells $(45,000)$ were plated in eight-well ibiTreat $\mu$-slides and incubated overnight. Cells were washed with HBSS and incubated with Lgmn (100 nM final in HBSS pH 5.5) or trypsin (10 nM final in HBSS pH 7.4; $1 \mathrm{~h} 37^{\circ} \mathrm{C}$ ). Cells were fixed in $4 \%$ paraformaldehyde on ice for $10 \mathrm{~min}$. Cells were incubated with blocking buffer [3\% normal horse serum (NHS) and $0.1 \%$ saponin] for $30 \mathrm{~min}$ at RT. Primary antibodies in blocking buffer [rabbit anti-FLAG (1:250, Rockland) and mouse anti-HA (1:250; Ray Biotech)] were incubated overnight at $4^{\circ} \mathrm{C}$. Cells were washed with PBS and secondary antibodies in blocking buffer (donkey anti-rabbit-Alexa Fluor 488 and donkey anti-mouse-Alexa Fluor 647; 1:500; ThermoFisher) were added for $1 \mathrm{~h}$ at RT. After washing with PBS, DAPI was added for $5 \mathrm{~min}$ followed by additional washing. Cells were imaged immediately on a Leica SP8 confocal microscope.

On-cell Westerns. HEK-FLAG-PAR 2 -HA cells were plated on poly-Dlysine (PDL)-coated 96-well plates (30,000 cells/well) and incubated overnight. Cells were washed two times in HBSS ( $\mathrm{pH}$ 7.4) and placed in MES-HBSS ( $\mathrm{pH}$ 5.0) for Lgmn assays or HBSS ( $\mathrm{pH}$ 7.4) for trypsin assays. Cells were incubated with Lgmn ( 1 or $10 \mathrm{ng} / \mu \mathrm{l}$ final concentration) in MES-HBSS ( $\mathrm{pH} 5.0$ ), trypsin (10 nM final concentration) in HBSS ( $\mathrm{pH} 7.4$ ), or vehicle (buffer control) for $30 \mathrm{~min}$ at $37^{\circ} \mathrm{C}$. Cells were washed with HBSS and fixed with 4\% paraformaldehyde in PBS for 20 min on ice. Cells were washed three times in PBS and incubated with blocking buffer (PBS $+3 \%$ NHS) for $1 \mathrm{~h}$ at room temperature. Cells were incubated with mouse anti-FLAG antibody (1:500, Cell Signaling) in $\mathrm{PBS}+1 \% \mathrm{NHS}$ overnight at $4^{\circ} \mathrm{C}$. Cells were washed three times in PBS, incubated with donkey anti-mouse Alexa Fluor 790 (1:1000, A11371, ThermoFisher) in PBS $+1 \%$ NHS for $1 \mathrm{~h}$ at room temperature. Cells were washed 1 time in PBS and incubated with the nuclear stain SYTO 82 Orange ( $1 \mu \mathrm{M}$, ThermoFisher) in saline for $30 \mathrm{~min}$. Cells were washed three times with saline and then imaged on an GE HealthcareTyphoon imaging system (GE). FLAG immunofluorescence intensity was quantified using NIH ImageJ and was normalized to nuclear fluorescent intensity to correct possible cell loss.

Measurement of intracellular $\mathrm{Ca}^{2+}$. HEK-FLAG-PAR $-\mathrm{HA}$ cells were plated on PDL-coated 96-well plates (25,000 cells/well) and incubated overnight. Cells were loaded with fura-2 AM (1 $\mu \mathrm{M}$, Cayman Chemicals) in loading buffer $\left(150 \mathrm{~mm} \mathrm{NaCl}, 2.6 \mathrm{~mm} \mathrm{KCl}, 0.1 \mathrm{~mm} \mathrm{CaCl}_{2}, 1.18 \mathrm{~mm}\right.$ $\mathrm{MgCl}_{2}, 10 \mathrm{~mm}$ D-glucose, $10 \mathrm{~mm}$ HEPES, $4 \mathrm{~mm}$ probenecid, 0.5\% BSA, $\mathrm{pH} \mathrm{7.4)} \mathrm{for} 1 \mathrm{~h}$ at $37^{\circ} \mathrm{C}$. Cells were washed 2 times in HBSS and then placed in MES-HBSS ( $\mathrm{pH} 5.0,5.5,6.0$, or 7.4) for the Lgmn assays or HBSS (pH 7.4) for trypsin assays. Fluorescence was measured with 340 or $380 \mathrm{~nm}$ excitation and $530 \mathrm{~nm}$ emission with a Flexstation three plate reader. Baseline fluorescence was measured for $45 \mathrm{~s}$ (Zhao et al., 2015). Cells were challenged with Lgmn ( 1 or $10 \mathrm{ng} / \mu \mathrm{l}$ final concentration) in MESHBSS ( $\mathrm{pH} 5.0,5.5,6.0$, or 7.4), trypsin (10 nm final concentration) in HBSS ( $\mathrm{pH} 7.4$ ), or vehicle (buffer control), and fluorescence was measured for an
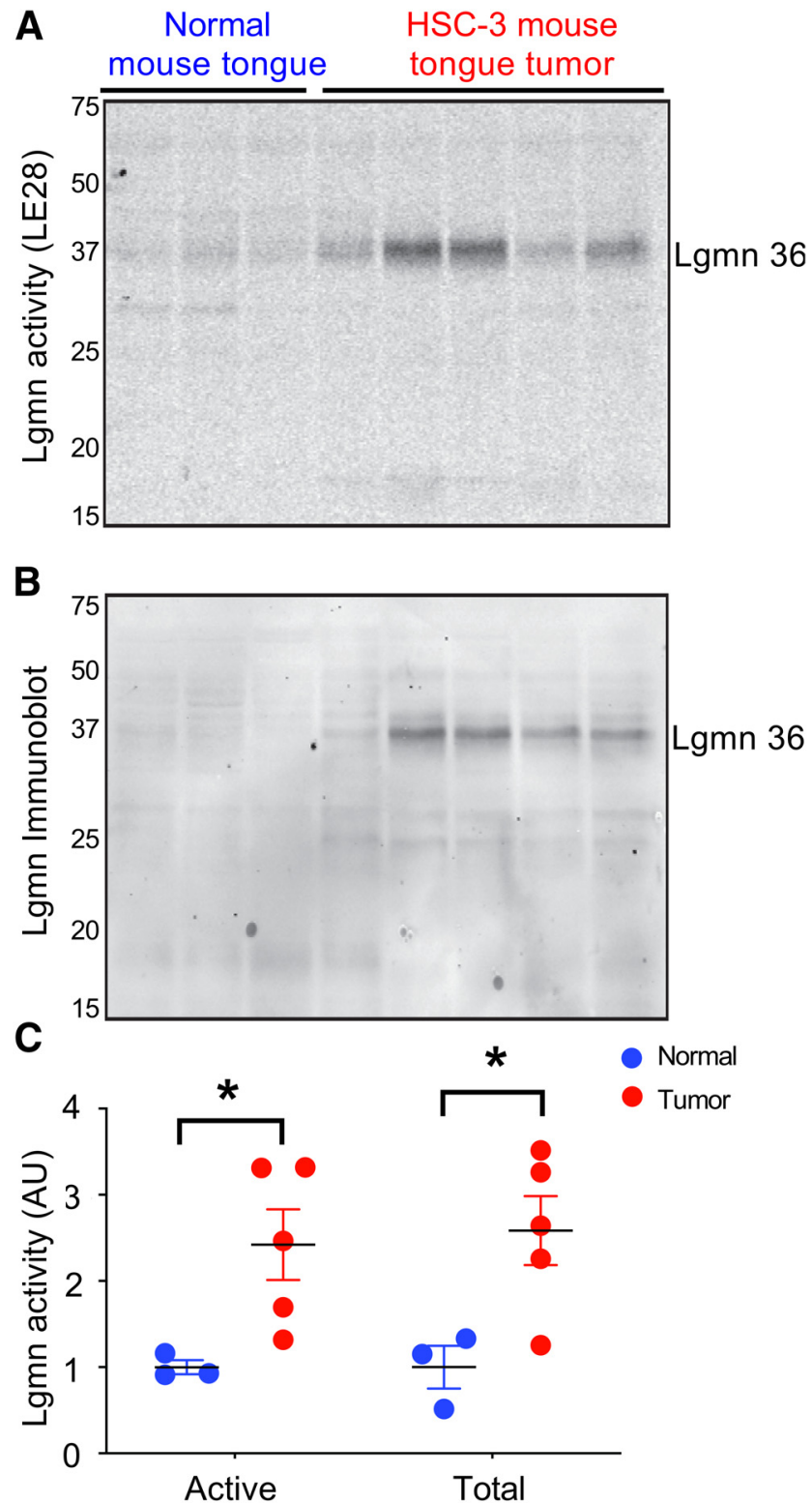

Figure 2. Lgmn in xenograft model of OSCC. $A, B$, Active Lgmn labeled by LE28 ( $A)$, shown by in-gel fluorescence, and total Lgmn immunoreactivity $(\mathbb{R} ; \boldsymbol{B})$, shown by Western blotting of lysates from HSC-3 xenografts or control tongues. The gel from $(\boldsymbol{A})$ was transferred to nitrocellulose and immunoblotted for total Lgmn levels $(\boldsymbol{B})$. $\boldsymbol{C}$, Densitometry of active and total $\operatorname{Lgmn}$ from $\boldsymbol{A}, \boldsymbol{B}$, respectively $\left(n=3-5, t_{(6)}=2.592,{ }^{*} p=0.0411\right.$, when active Lgmn in normal mouse tongue and xenograft cancer is compared, and $t_{(6)}=2.818$, ${ }^{*} p=0.0304$, when total Lgmn in normal mouse tongue xenograft cancer is compared, unpaired Student's $t$ tests).

additional $180 \mathrm{~s}$. To confirm that Lgmn-induced $\mathrm{Ca}^{2+}$ responses were because of activation of $\mathrm{PAR}_{2}$, cells were incubated with the $\mathrm{PAR}_{2}$ antagonists I-343 (10 $\mu \mathrm{M})$ or GB88 (10 $\mu \mathrm{M}$; Farmer, 2013; Lieu et al., 2016; Jimenez-Vargas et al., 2018), the $\mathrm{PAR}_{1}$ antagonist SCH79797 (200 nм; Ahn et al., 2000), or vehicle in HBSS $+1 \%$ DMSO for $1 \mathrm{~h}$ at $37^{\circ} \mathrm{C}$ before the $\mathrm{Ca}^{2+}$ assay. To confirm the requirement for protease activity, Lgmn was incubated with the Lgmn inhibitors QDD100531 (1 $\mu \mathrm{M})$ or QDD123427 (100 nM; Ness et al., 2015) in HBSS $+1 \%$ DMSO for $1 \mathrm{~h}$ before the $\mathrm{Ca}^{2+}$ assay. Cells were maintained with the inhibitors. To assess the requirement for hydrolyzis of the $\mathrm{Asn}^{30} \downarrow \mathrm{Arg}^{31}$ site, a mutant $\mathrm{PAR}_{2}$ in which $\mathrm{Asn}^{30}$ was replaced with Ala $\left(\mathrm{PAR}_{2}-\triangle \mathrm{N} 30 \mathrm{~A}\right)$ was generated (Twist Biosciences, San Francisco, CA). cDNA $(5 \mu \mathrm{g})$ encoding $\mathrm{PAR}_{2}-\Delta \mathrm{N} 30 \mathrm{~A}$ was expressed in HEK-PAR ${ }_{2}-\mathrm{KO}$ cells using polyethylenimine (ratio 1:6, DNA:PEI), and cells were studied after $48 \mathrm{~h}$. To assess the capacity of Lgmn or trypsin to 
desensitize $\mathrm{PAR}_{2}$-mediated $\mathrm{Ca}^{2+}$ signaling, HEK-FLAG-PAR ${ }_{2}$-HA cells were preincubated with Lgmn ( 1 or $10 \mathrm{ng} / \mu \mathrm{l}$ final concentration) in MES-HBSS ( $\mathrm{pH} 5.0$ ), trypsin (10 nM final concentration) in HBSS ( $\mathrm{pH} 7.4$ ), or vehicle (buffer control) for $10 \mathrm{~min}$ at $37^{\circ} \mathrm{C}$. Cells were washed and recovered in HBSS ( $\mathrm{pH}$ 7.4) for $20 \mathrm{~min}$ at $37^{\circ} \mathrm{C}$. Cells were then challenged with trypsin (10 nM). Desensitization of $\mathrm{Ca}^{2+}$ signals to the second challenge with trypsin was calculated as a percentage of the responses in cells preincubated with the vehicle control.

FRET assays of $c A M P$, protein kinase $D$ $(P K D)$, and ERK. Genetically encoded FRET biosensors targeted to the cytosol were used to assess cAMP, PKD and ERK activation in living cells in real time (Zhao et al., 2015). HEKFLAG-PAR 2 -HA cells were transfected with cDNA $(5 \mu \mathrm{g})$ encoding the cAMP biosensor Cyto-EPAC (Jimenez-Vargas et al., 2018), the PKD biosensor Cyto-DKAR (Zhao et al., 2019), or the ERK biosensor Cyto-EKAR (Yarwood et al., 2017) using polyethylenimine (ratio 1:6, DNA:PEI). Cells were plated on PDL-coated 96-well plates (25,000 cells/well) and incubated overnight. Cells were washed $2 \times$ in HBSS and placed in MES-HBSS $(\mathrm{pH}$ 5.0) for the Lgmn assays. The cyan (470 nM) and yellow fluorescent protein (535 nм) emission ratios were measured with a CLARIOstar $^{\text {Plus }}$ plate reader (BMG). Baseline fluorescent ratios were recorded for $5 \mathrm{~min}$. Cells were challenged with Lgmn (1 or $10 \mathrm{ng} /$ $\mu \mathrm{l}$ ) in MES-HBSS ( $\mathrm{pH}$ 5.0) or vehicle (buffer control), and FRET was measured for an additional $30 \mathrm{~min}$. FRET ratios were normalized to the MES-HBSS vehicle control.

BRET assays of $\beta$-arrestin recruitment. HEK293 cells were transfected with cDNA encoding the $\mathrm{PAR}_{2}$-RLuc8 $(1 \mu \mathrm{g})$ and $\beta$ arrestin-1-YFP $(4 \mu \mathrm{g})$ with polyethylenimine (ratio 1:6, DNA:PEI; Jensen et al., 2013). Cells were plated on PDL-coated 96-well white walled plates (30,000 cells/well) and incubated overnight. Cells were washed $2 \times$ in HBSS and placed in MES-HBSS ( $\mathrm{pH}$ 5.0) for the Lgmn assays or HBSS ( $\mathrm{pH}$ 7.4) for trypsin assays. Coelenterazine-h (5 $\mu \mathrm{M}$, Nanolight, Pinetop AZ) was added to the cells and the cells were challenged with Lgmn ( 1 or $10 \mathrm{ng} / \mu \mathrm{l})$ or tryp$\sin (10 \mathrm{nM})$. RLuc8 luminescence $(480 \mathrm{~nm})$ and YFP fluorescence $(530 \mathrm{~nm})$ emission were measured using a CLARIOstar ${ }^{\text {Plus }}$ plate reader. Baseline fluorescence ratios were recorded for $2.5 \mathrm{~min}$. The BRET ratio was normalized to vehicle control and baseline.

Experimental design and statistical analysis. We used GraphPad Prism 7 and 8 (GraphPad Prism, GraphPad Software) for the statistical analysis. Results are expressed as mean \pm SEM. For cell-based assays, triplicate measurements were made from four to five experiments; differences were evaluated by one-way or two-way ANOVA and Dunnett's or Tukey's multiple comparisons test. One-way ANOVA and Tukey's or Sidak's multiple comparisons and Student's $t$ test were used for in vivo behavioral experiments and comparison of rheobase. Unpaired Student's $t$ test was used to compare values between two groups.

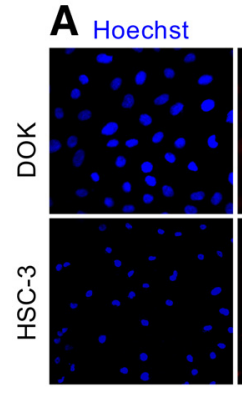
HSC-3 cell supernatant.
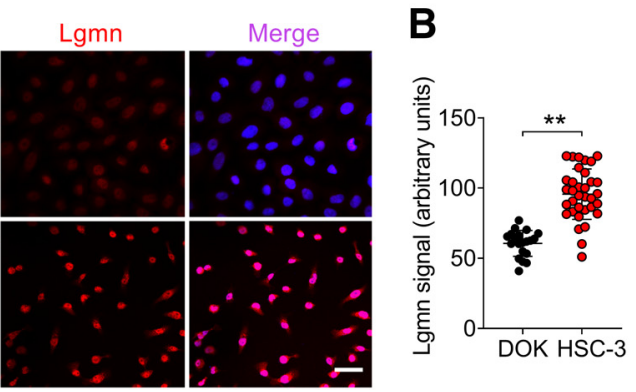

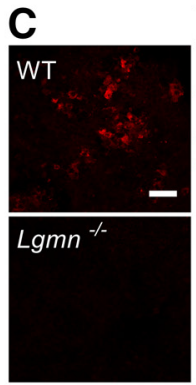

D

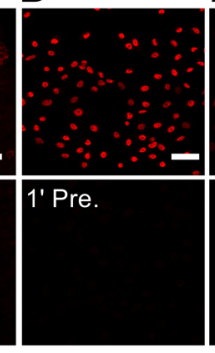

E
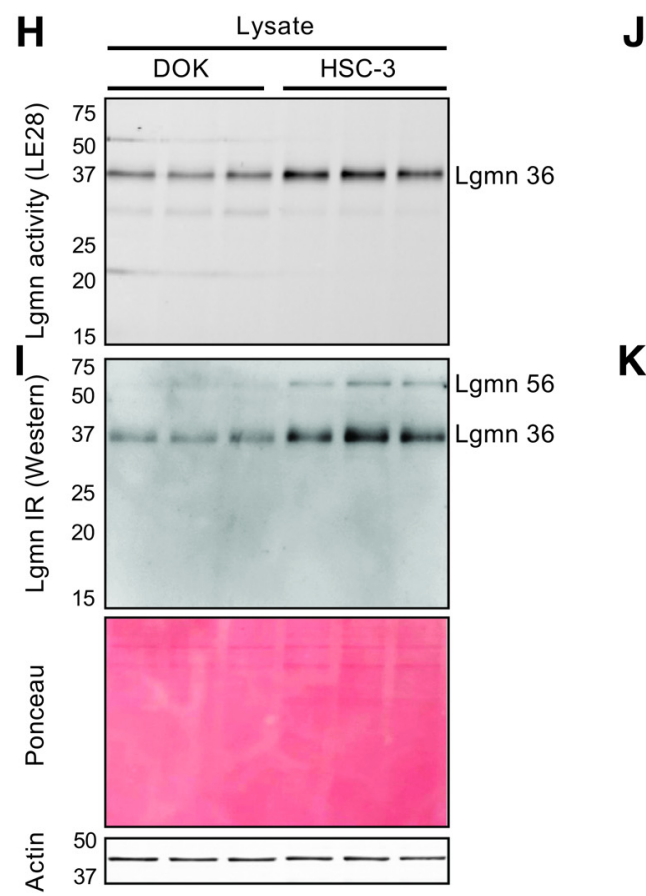

K

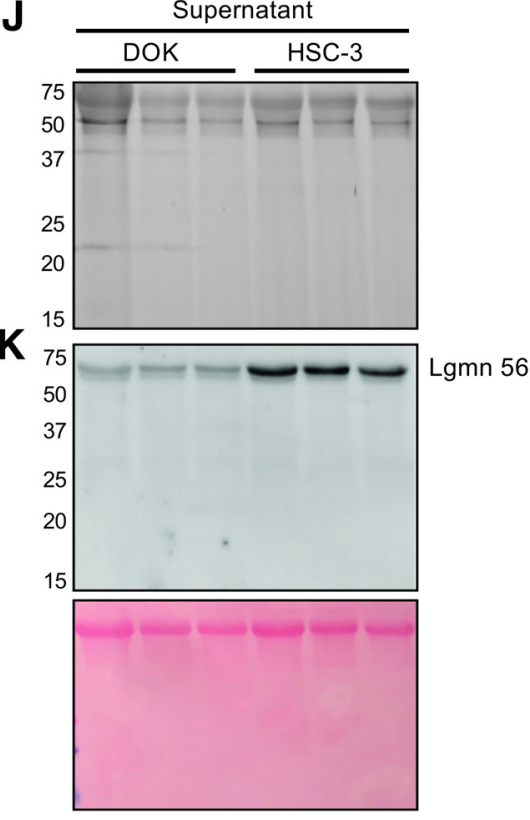

$\mathbf{F}$

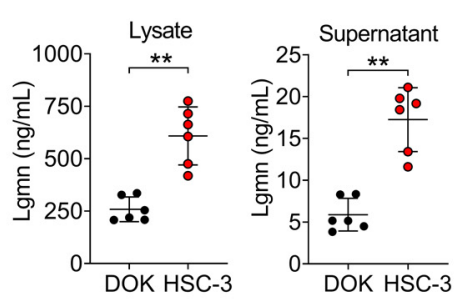

$\mathbf{J}$
Figure 3. Expression of Lgmn in OSCC cells. $\boldsymbol{A}$, Localization of immunoreactive Lgmn (red) in DOK and HSC-3. $\boldsymbol{B}$, Lgmn signal intensity in DOK and HSC-3 was quantified in individual cells by NIH ImageJ $\left(t_{(52)}=8.11,{ }^{* *} p=8.53 \mathrm{E}-11\right.$, when Lgmn signal of DOK is compared with HSC-3, $n=20$ and 34 cells in DOK and HSC-3, respectively, unpaired Student's $t$ test). C, Localization of immunoreactive Lgmn in the spleen of WT and $\mathrm{Lgmn}^{-1-}$ mice. $\boldsymbol{D}$, Preabsorption of Lgmn antibody with Lgmn eliminated HSC-3 staining. $\boldsymbol{E}$, Omission of the anti-Lgmn antibody resulted in lack of HSC-3 staining. $\boldsymbol{F}, \boldsymbol{G}$, Quantification of Lgmn protein by ELISA in DOK and HSC-3 cell lysate and supernatant. The concentration of Lgmn in HSC-3 cell lysate and supernatant was three times higher than that of DOK. $N=6$ experiments in each group (in $\boldsymbol{F}_{,} t_{(10)}=5.70$, ${ }^{* *} p=0.0002$, when the Lgmn concentration in supernatant from HSC -3 is compared with the Lgmn protein concentration in supernatant from DOK, unpaired Student's $t$ test. In $G, t_{(10)}=6.49,{ }^{* *} p=0.000069$, when the Lgmn concentration in lysate from HSC-3 is compared with the Lgmn concentration in lysate from DOK, unpaired Student's $t$ test). Scale bar in $A, C, D, E$ : $50 \mu \mathrm{m}$. $\boldsymbol{H}$, Labeling of active Lgmn with LE28 in DOK and HSC-3 cell lysate, as shown by in-gel fluorescence. $\boldsymbol{I}$, Lgmn immunoblot in DOK and HSC-3 cell lysate in $\boldsymbol{H}$, with ponceau stain and actin immunoblot to verify equal loading. $\boldsymbol{J}$, Labeling of Lgmn with LE28 in DOK and HSC-3 cell supernatant, as shown by in-gel fluorescence. $\boldsymbol{K}$, Immunoblot of Lgmn from DOK and

\section{Results}

Lgmn is activated in human and murine OSCC

To determine whether Lgmn is activated in OSCCs, we collected OSCC specimens and matched normal oral mucosa from seven 
A

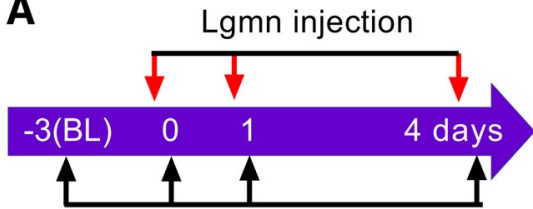

Paw von Frey filament assay (C)

Facial von Frey filament assay (E)

Dolognawmeter assay (F)

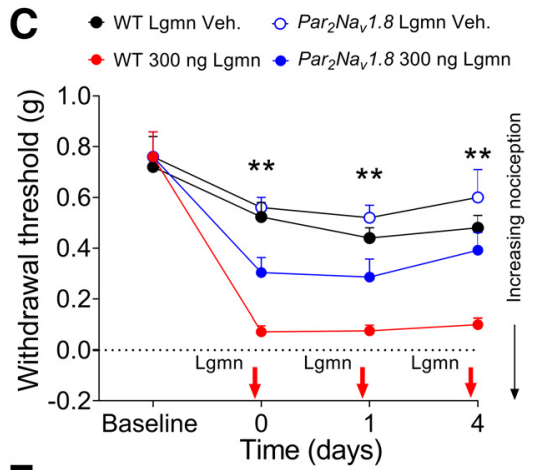

E

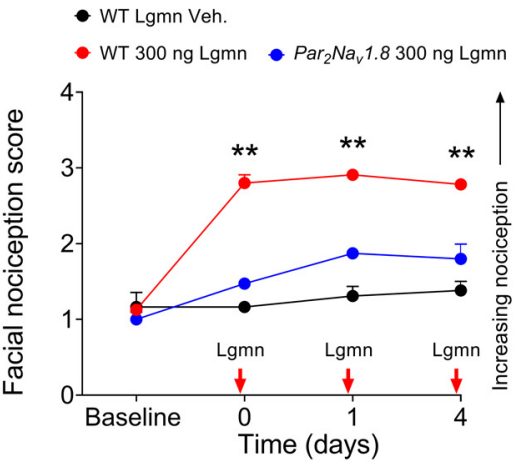

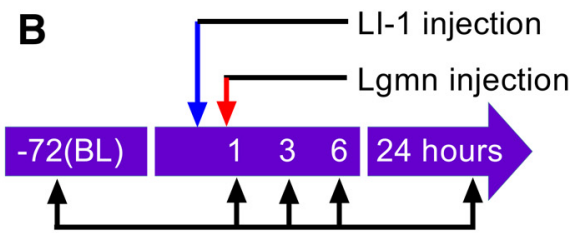

Paw von Frey filament assay (D)

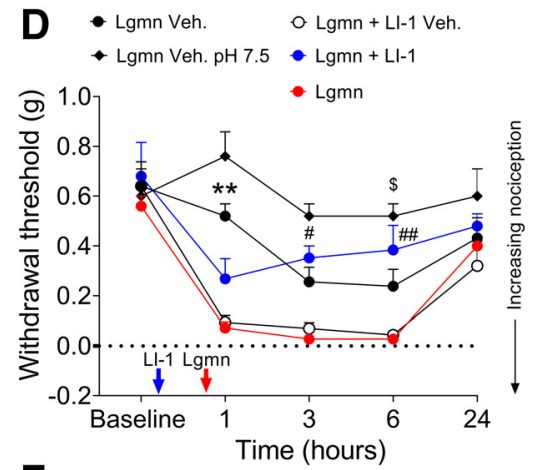

$\mathbf{F}$

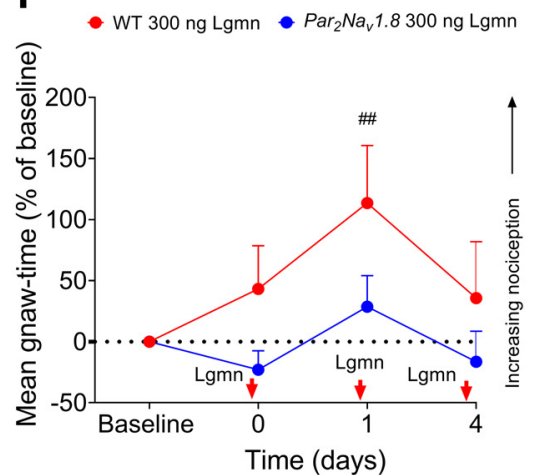

Figure 4. Lgmn-evoked nociception. $\boldsymbol{A}$, Experiment timeline to test the effect of Lgmn (red arrow) on paw, facial mechanical nociception, and oral function on WT and $\mathrm{Par}_{2} \mathrm{Na}_{v} 1.8$ mice. $\boldsymbol{B}$, Experiment timeline to test the effect of Lgmn (red arrow) and LI-1 (blue arrow) on paw mechanical nociception on WT mice. C, Effects of Lgmn or vehicle (Veh) on paw withdrawal in WT and $\mathrm{Par}_{2} \mathrm{Na}_{v} 1.8$ mice. Arrows indicate time of Lgmn or vehicle injection. Relative to WT Veh. mice, withdrawal thresholds were significantly lower in WT Lgmn mice, but not Par ${ }_{2} \mathrm{Na}_{v} 1.8$ mice, at days 0,1 , and 4 (interaction $F_{(9,64)}=2.47, p=0.02$; ${ }^{* *} p=0.0002$ at $\mathrm{d} 0,{ }^{* *} p=0.0033$ at d1, ${ }^{* *} p=0.002$ at $\mathrm{d} 4$, respectively, when WT mice treated with $300 \mathrm{ng}$ Lgmn are compared with WT mice treated with Lgmn vehicle, $n=5$ in each group, two-way ANOVA, Tukey's multiple comparisons). $\boldsymbol{D}$, Effects of LI- 1 on Lgmn-evoked mechanical allodynia in WT mice. Blue arrow indicates time of LI-1 or vehicle administration. Red arrow indicates time of Lgmn or Lgmn vehicle injection. Withdrawal thresholds were measured at 1, 3, 6, and $24 \mathrm{~h}$ after Lgmn injection. The effect of Lgmn varied with time (interaction $F_{(16,100)}=2.98, p=0.005$, two-way ANOVA, $n=5$ in each group, Tukey's multiple comparisons). One hour after injection of LI-1, mean withdrawal threshold was lower in Lgmn versus Lgmn vehicle $\left.{ }^{* *} p=0.0002\right)$. LI-1 prevented the nociceptive effect of Lgmn at 3 and $6 \mathrm{~h}$ after Lgmn injection $\left({ }^{\#} p=0.04\right.$ and ${ }^{\# \#} p=0.009$, respectively, when Lgmn plus LI- 1 is compared with Lgmn plus LI-1 vehicle), but not $1 \mathrm{~h}$ after LI-1 injection $(p=0.30)$. Lgmn Veh. at pH 5 reduced the withdrawal threshold more than Lgmn Veh. at pH 7.5 at $6 \mathrm{~h}$ after paw injection $\left(F_{(4,100)}=24.5, \$ p=0.04\right.$, when Lgmn Veh. at $\mathrm{pH} 5.0$ is compared with Lgmn Veh. at pH 7.5, two-way ANOVA, Tukey's multiple comparisons). $\boldsymbol{E}$, Lgmn ( $300 \mathrm{ng}$ ) was injected into the cheek at days 0 , 1 , and 4 following baseline facial withdrawal measurements. Arrows indicate Lgmn injection into the cheek. Lgmn induced facial mechanical allodynia in WT but not $\mathrm{Par}_{2} \mathrm{Na}_{v} 1.8$ mice. The means of the facial nociception score were significantly increased in WT mice versus Par $_{2} \mathrm{Na}_{v} 1.8$ mice at days 0,1 , and $4\left(F_{(3,36)}=71.69,{ }^{* *} p=2.98 \mathrm{E}-15\right.$ at d0, d1, and d4, when WT 300 ng Lgmn is compared with $\mathrm{Par}_{2} \mathrm{Na}_{v} 1.8300 \mathrm{ng}$ Lgmn, $n=5$ in each group, two-way ANOVA, Sidak's multiple comparisons). F, Lgmn (300 ng) significantly increased gnaw-time at $1 \mathrm{~d}$ after injection in WT mice versus baseline, but not in $\mathrm{Par}_{2} \mathrm{Na}_{v} 1.8$ mice $\left(F_{(3,33)}=3.26,{ }^{\#} p=0.0045\right.$ at d1, when WT $300 \mathrm{ng}$ Lgmn is compared with baseline, $n=8$ and 6 in WT and $\mathrm{Par}_{2} \mathrm{Na}_{v} 1.8$ mice, respectively, two-way ANOVA, Tukey's multiple comparisons).

patients (Table 1). Specimens were incubated with a fluorescently quenched activity-based probe (LE28) selective for Lgmn (Edgington et al., 2013). Two LE28-labeled species of $36 \mathrm{kDa}$ and $25 \mathrm{kDa}$ were activated in OSCC versus normal tissue (Fig. $1 A-D$ ). Immunoprecipitation with a Lgmn-specific antibody confirmed the identity of mature forms of Lgmn (Fig. 1D). Immunoblotting revealed total levels of mature Lgmn $36 \mathrm{kDa}$ increased in all OSCC versus normal tissue (Fig. 1A). The $56 \mathrm{kDa}$ inactive Lgmn zymogen (pro-Lgmn) was detected in all specimens. Total Lgmn and Lgmn activity of $36 \mathrm{kDa}$ were upregulated in a murine OSCC xenograft model (human OSCC cells (HSC-3) inoculated in nude mouse tongues) versus normal (Fig. $2 A-C$ ).

We examined Lgmn expression in HSC-3 and dysplastic oral keratinocytes (DOK, non-cancer cell line) by immunofluorescence and ELISA. Immunoreactive Lgmn was detected in cytosolic granules of HSC-3 and DOK cells, and expression was confirmed by ELISA of cell lysate and conditioned medium (supernatant; Fig. $3 A, F, G)$. The intensity of Lgmn staining was higher in HSC-3 (Fig. $3 B$ ). Controls for the selectivity of the Lgmn antibody included absence of staining of spleen from $\mathrm{Lgmn}^{-/-}$ mice (Fig. 3C), abolition of Lgmn staining by Lgmn antibody preabsorption with Lgmn (Fig. 3D), and lack of staining when the Lgmn antibody was omitted (Fig. 3E). The Lgmn protein concentration in lysate and supernatant from HSC-3 was higher than the concentration from DOK (Fig. 3F,G). The levels of Lgmn in lysate (Fig. $3 H, I$ ) and supernatant (Fig. 3J,K) were higher in HSC-3 compared with DOK. Immunoblotting revealed upregulation of Lgmn $56-\mathrm{kDa}$ zymogen and Lgmn $36-\mathrm{kDa}$ mature form in HSC-3 versus DOK (Fig. 3I). HSC-3 cells also secreted more proLgmn than DOKs (Fig. 3J,K). These results suggest that OSCC cells express and release more Lgmn than dysplastic keratinocytes.

\section{$\mathrm{PAR}_{2}$ expression on $\mathrm{Na}_{\mathrm{V}} 1.8$ -} positive nociceptors is necessary for Lgmn-induced mechanical allodynia

To investigate whether Lgmn causes allodynia by activating $\mathrm{PAR}_{2}$ on nociceptors, we administered Lgmn (300 ng intraplantar injection) for $3 \mathrm{~d}(0,1,4 \mathrm{~d})$ to WT $(\mathrm{C} 57 \mathrm{BL} / 6 \mathrm{~J})$ and $\mathrm{Par}_{2} \mathrm{Na}_{v} 1.8$ mice, which lack $\mathrm{PAR}_{2}$ in $\mathrm{Na}_{\mathrm{V}} 1$.8-positive neurons. We measured paw withdrawal responses to stimulation of the plantar surface with von Frey filaments at baseline and $1 \mathrm{~h}$ after each Lgmn injection (Fig. 4A). Lgmn induced mechanical allodynia on all $3 \mathrm{~d}$ in WT mice; however, mechanical allodynia was attenuated in $\mathrm{Par}_{2} \mathrm{Na}_{v} 1.8$ mice by $51 \%$ on day 0 
A

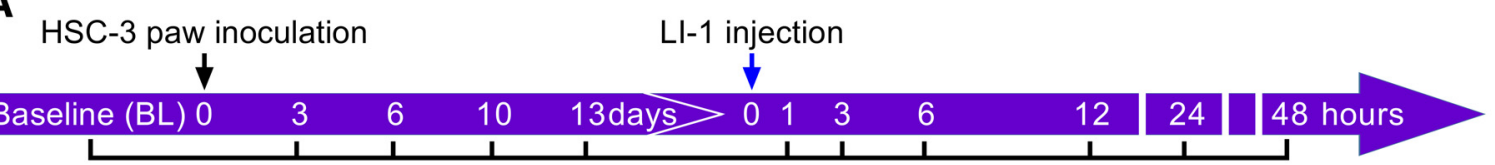

B

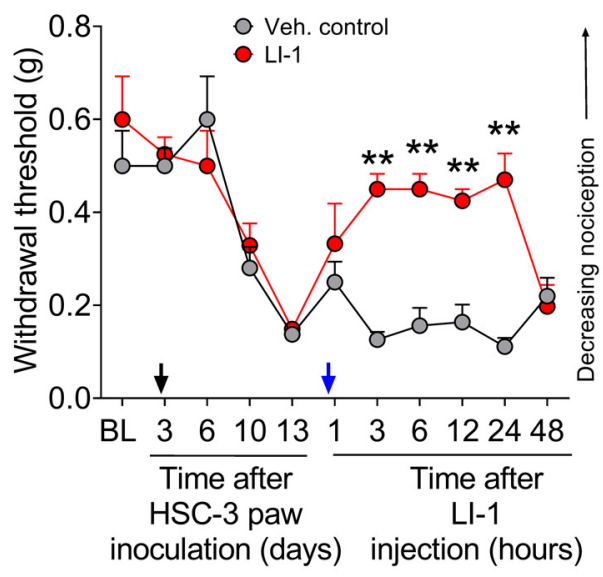

C

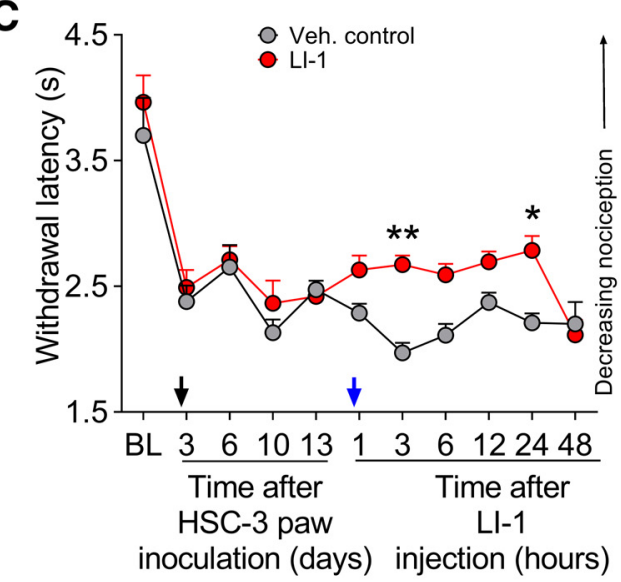

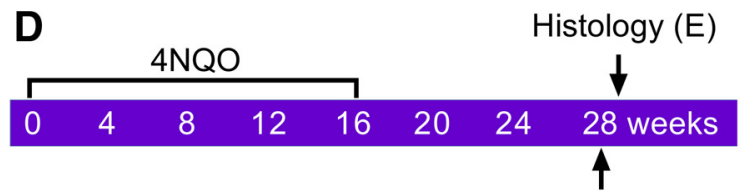

Dolognawmeter assay $(G)$
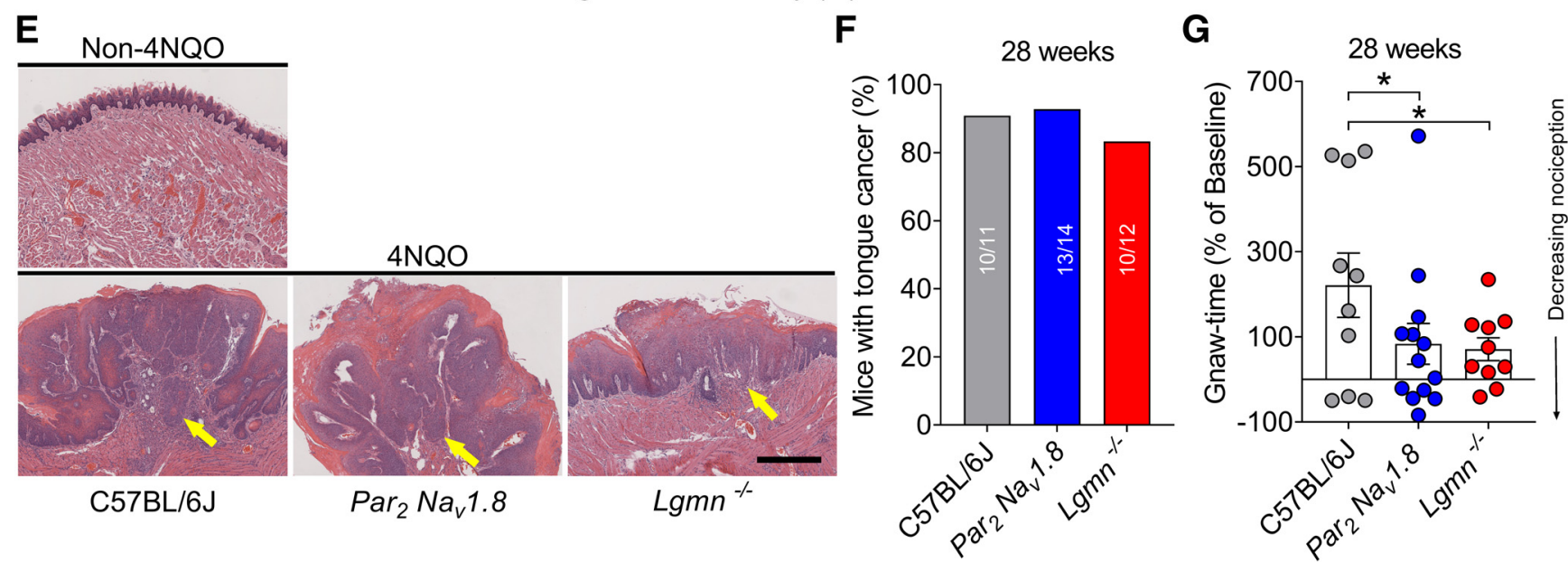

Figure 5. Contributions of $\mathrm{Lgmn}$ and $\mathrm{PAR}_{2}$ to $\mathrm{OSCC}$ pain. $A$, The experimental protocol included baseline measurements of withdrawal threshold to mechanical stimulation and withdrawal latency to thermal stimulation, HSC-3 inoculation, injection of LI-1, and measurements of nociception. $\boldsymbol{B}$, Mechanical allodynia. HSC-3 inoculation (black arrow) produced mechanical allodynia after $10 \mathrm{~d}$. Ll-1 (blue arrow) reversed cancer-induced mechanical nociception versus vehicle control after 3, 6, 12, and $24 \mathrm{~h}$ following injection but not after $48 \mathrm{~h}\left(F_{(1,77)}=32.42\right.$, ${ }^{* *} p=0.0003$ at $3 \mathrm{~h},{ }^{* *} p=0.0015$ at $6 \mathrm{~h},{ }^{* *} p=0.0068$ at $12 \mathrm{~h},{ }^{* *} p=2.15 \mathrm{E}-07$ at $24 \mathrm{~h}$, when Veh. control is compared with LI-1, $n=8$ in each group, two-way ANOVA, Sidak's multiple comparisons). C, Thermal hyperalgesia. HSC-3 inoculation (black arrow) produced thermal hyperalgesia beginning at $3 \mathrm{~d}$. LI-1 (blue arrow), versus vehicle control, reduced thermal hyperalgesia after 3 and $24 \mathrm{~h}$ but not after $48 \mathrm{~h}\left(F_{(10,140)}=24.45,{ }^{* *} p=0.0029\right.$ at $3 \mathrm{~h},{ }^{*} p=0.0278$ at $24 \mathrm{~h}$, when Veh. control is compared with LI-1, $n=8$ in each group, two-way ANOVA, Sidak's multiple comparisons). $D$, The experimental protocol included administration of $4 \mathrm{NQO}$ to the mice for 16 weeks, measurement of OSCC nociception (gnaw-time) with the dolognawmeter, and histologic analysis of the tongue to confirm cancer. $\boldsymbol{E}$, Representative histologic images of the tongue from $\mathrm{C} 57 \mathrm{BL} / 6 \mathrm{~J}$ mice that did not receive $4 \mathrm{NQ0}$, and of the tongues from $\mathrm{C}^{2} \mathrm{BL} / 6 \mathrm{~J}$, Par $2 \mathrm{Na}_{\mathrm{v}} 1.8$, and

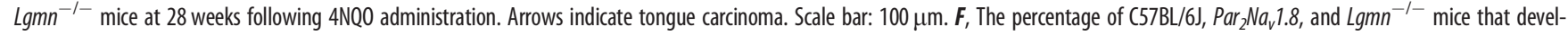
oped tongue cancer at 28 weeks after 4 NQ0 administration. $\mathbf{G}$, Change of gnaw-time versus baseline (percentage change of gnaw-time at baseline was set as $0 \%$; data not shown) of C57BL/6J $(n=10), \operatorname{Par}_{2} \mathrm{Na}_{v} 1.8(n=13)$, and $\mathrm{Lgmn}^{-1-}(n=10)$ mice with 4NQ0-induced tongue cancer $\left(F_{(1,30)}=16.28,{ }^{*} p=0.029\right.$, when $\mathrm{C57BL} / 6 \mathrm{~J}$ is compared with $\mathrm{Par}_{2} \mathrm{Na}_{v} 1.8,{ }^{*} p=0.024$, when C57BL/6J is compared with $\mathrm{Lgmn}^{-1-}$, two-way ANOVA with Tukey's multiple comparisons).

(Fig. 4C). To confirm that the nociceptive action of Lgmn required enzymatic activity and to test the analgesic potential of a Lgmn inhibitor, we administered the Lgmn-selective inhibitor, LI-1 (10 $\mathrm{mm}, 100 \mu$ l, i.v.; Edgington-Mitchell, 2016) to WT mice $120 \mathrm{~min}$ before intraplantar injection of Lgmn and measured paw withdrawal at 1, 3, 6, and $24 \mathrm{~h}$ after Lgmn injection (Fig. 4B). LI-1 attenuated Lgmn-induced mechanical allodynia by $44 \% 1 \mathrm{~h}$ after Lgmn injection (Fig. 4D). Thus, Lgmn-induced mechanical allodynia in mice requires $\mathrm{PAR}_{2}$ expression on $\mathrm{Na}_{\mathrm{v}} 1.8$-expressing nociceptors and Lgmn enzymatic activity. 
$\mathbf{A}_{\mathrm{WT}}$

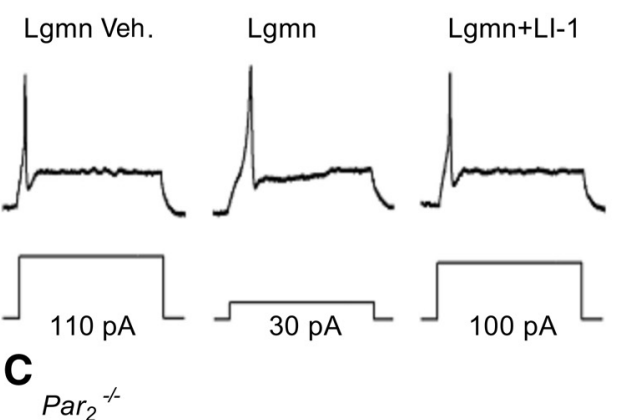

Lgmn Veh.

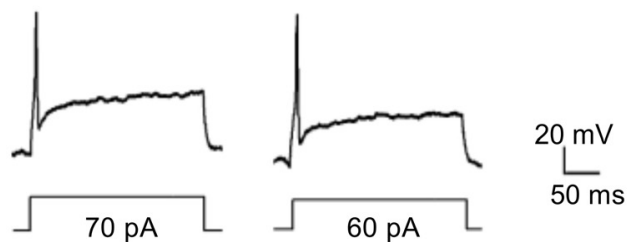

E

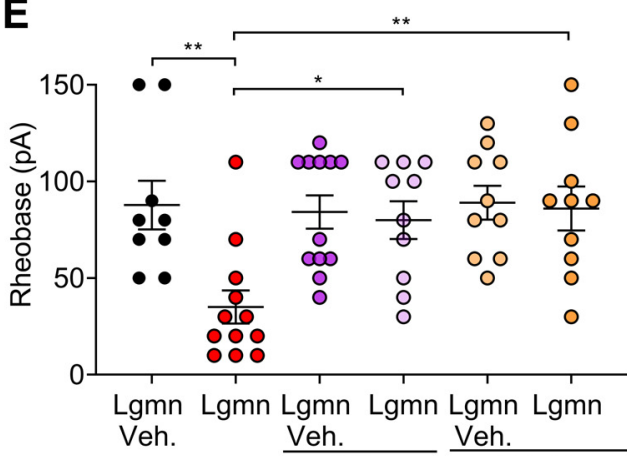

GFX

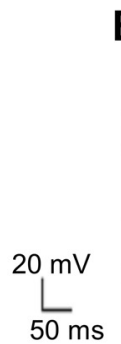

B
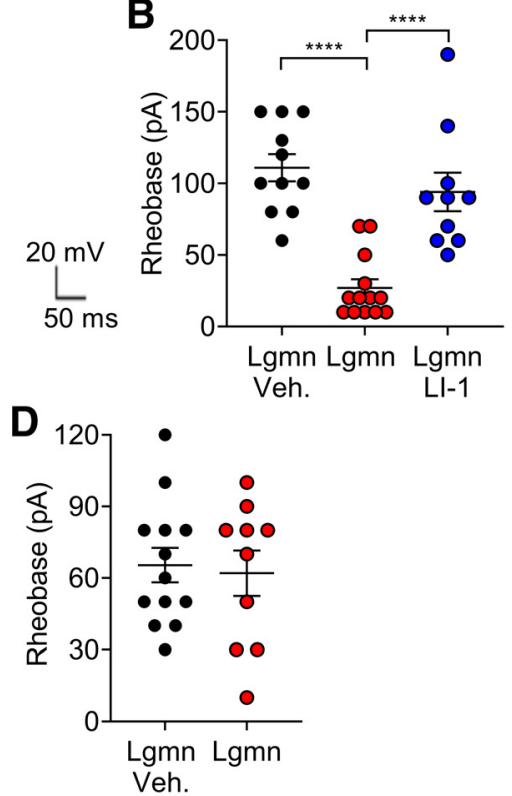

Figure 6. $P A R_{2}$ mediated Lgmn-induced hyperexcitability in TG neurons. $\boldsymbol{A}$, Representative raw traces of whole-cell patchclamp recordings showing membrane potential response at rheobase of TG neurons from WT mice treated with Lgmn vehicle, Lgmn, and Lgmn + LI-1. B, Rheobase of TG neurons in different treatment groups. Lgmn vehicle: $110.0 \pm 31.4 \mathrm{pA}, n=11$ Lgmn: $26.9 \pm 22.1 \mathrm{pA}, n=13 ;$ Lgmn + LI-1: $94.0 \pm 42.4 \mathrm{pA}, n=10\left(F_{(2,31)}=23.14,{ }^{* * * *} p=1.23 \mathrm{E}-6\right.$, when Lgmn and Lgmn vehicle are compared, ${ }^{* * *} p=6.93 \mathrm{E}-5$, when Lgmn and Lgmn + Ll-1 are compared, one-way ANOVA with Tukey's multiple comparisons). C, Representative raw traces of whole-cell patch-clamp recordings showing membrane potential response at rheobase of TG neurons from $\mathrm{Par}_{2}{ }^{-1-}$ mice treated with Lgmn and Lgmn vehicle. $\boldsymbol{D}$, Rheobase of TG neurons from $\mathrm{Par}_{2}{ }^{-1-}$ mice. Lgmn vehicle: $65.3 \pm 26.0 \mathrm{pA}, n=13$; Lgmn: $62.0 \pm 30.1 \mathrm{pA}, n=10$. $\boldsymbol{E}$, Lgmn induced hyperexcitability and PKC-dependent or PKA-dependent pathways. Perforated patch-clamp recordings were used to measure rheobase of TG neurons. Neurons were preincubated with GFX $1 \mu \mathrm{m}$ and PKI-tide $1 \mu \mathrm{m}$ before Lgmn or Lgmn vehicle treatments. Rheobase was measured after neurons were challenged with Lgmn and Lgmn vehicle. Lgmn vehicle, $87.7 \pm 12.5 \mathrm{pA}, n=9$; Lgmn, $35.6 \pm 8.5 \mathrm{pA}$, $n=12 ; \mathrm{GFX}+$ Lgmn vehicle, 84.1 $\pm 8.5 \mathrm{pA}, n=12 ; \mathrm{GFX}+$ Lgmn, $80.0 \pm 9.7 \mathrm{pA}, n=10 ;$ PKI-tide + Lgmn vehicle, $89.0 \pm 8.7 \mathrm{pA}, n=10$; PKI-tide $+\operatorname{Lgmn}, 86.0 \pm 11.3 \mathrm{pA}, n=10\left(F_{(5,57)}=4.93,{ }^{* *} p=0.0052\right.$, when Lgmn and Lgmn vehicle are compared, ${ }^{*} p=0.0198$ when the Lgmn and Lgmn + GFX are compared, ${ }^{* *} p=0.0198$, when Lgmn and Lgmn + PKItide are compared, one-way ANOVA with Tukey's multiple comparisons).

$\mathrm{PAR}_{2}$ expression on $\mathrm{Na}_{\mathrm{V}} 1.8$-positive nociceptors is necessary for Lgmn-induced orofacial nociception

We used reflexive and operant assays to test whether Lgmn induces nociception in the orofacial region. We injected Lgmn into the cheek and measured facial withdrawal to stimulation with von Frey filaments. Lgmn (300 ng) was injected subcutaneously for $3 \mathrm{~d}(0,1,4 \mathrm{~d})$ to WT and $\mathrm{Par}_{2} \mathrm{Na}_{v} 1.8$ mice. Withdrawal was measured at baseline and $1 \mathrm{~h}$ after each injection (Fig. $4 A$ ). Lgmn induced facial mechanical allodynia on all $3 \mathrm{~d}$ in WT mice, but the nociceptive effect was attenuated in $\mathrm{Par}_{2} \mathrm{Na}_{v} 1.8$ mice by $81 \%$ on day 0 (Fig. $4 E$ ). For operant behavioral testing, Lgmn (300 ng) was injected into the tongue. Dolognawmeters quantified a behavioral index of nociception $1 \mathrm{~h}$ after injection (Fig. 4A). Lgmn induced orofacial dysfunction in WT but not $\mathrm{Par}_{2} \mathrm{Na}_{v} 1.8$ mice (Fig. $4 F$ ). Thus, expression of $\mathrm{PAR}_{2}$ in $\mathrm{Na}_{\mathrm{v}} 1.8$-expressing nociceptors is necessary for Lgmninduced pain.

Lgmn mediates OSCC nociception We used LI-1 to study whether Lgmn secreted from HSC-3 contributes to nociception in the xenograft paw cancer model. After measuring baseline mechanical withdrawal and thermal latency in the paws of NU/J Foxn $1^{n u}$ athymic mice, we inoculated HSC-3 cells, which highly express Lgmn (Fig. 5A). Postinoculation withdrawal measurements verified cancer-generated mechanical allodynia or thermal hyperalgesia. Mice were then treated with LI-1, and mechanical and thermal nociception were assessed (Fig. 5A). LI-1 reversed OSCCinduced mechanical withdrawal at 3,6, 12, and $24 \mathrm{~h}$ after injection (Fig. 5B), and reversed thermal hyperalgesia at 3 and $24 \mathrm{~h}$ postinjection (Fig. 5C). LI-1 had no effect $48 \mathrm{~h}$ postinjection. An OSCC mouse model was generated with 4NQO administered over 16 weeks in $\mathrm{Lgmn}^{-1-}, \mathrm{Par}_{2} \mathrm{Na}_{v} 1.8$ and WT mice. Oral mechanical allodynia was measured with dolognawmeters at week 28 . Tongues were removed, sectioned, stained with $\mathrm{H} \& \mathrm{E}$, and reviewed independently by two pathologists (Fig. 5D). OSCC was confirmed in all groups (Fig. $5 E)$. OSCC incidence was $>80 \%$ at 28 weeks after the administration of 4 NQO in all groups (Fig. 5F). $\mathrm{Lgmn}^{-1-}$ and $\mathrm{Par}_{2} \mathrm{Na}_{v} 1.8$ showed significantly less mechanical allodynia than the WT mice (Fig. 5G).

\section{Lgmn induces $\mathrm{PAR}_{2}$-dependent hyperexcitability of trigeminal neurons}

To determine whether Lgmn causes $\mathrm{PAR}_{2}$-dependent hyperexcitability of TG neurons, we measured rheobase in WT mice using whole-cell patch-clamp. Neurons were studied in acidic buffer (external solution, $\mathrm{pH}$ 5.5). Lgmn (20 ng/ml, $10 \mathrm{~min}$ ) decreased rheobase versus vehicle. There was no significant difference between the resting membrane potentials of TG neurons from WT mice pretreated with Lgmn versus Lgmn vehicle (Lgmn: $-55.7 \pm 2.2 \mathrm{mV}, n=13$; Lgmn vehicle: $-56.6 \pm 3.9 \mathrm{mV} ; n=11, t_{(22)}=0.207, p=0.8378$, unpaired Student's $t$ test). The mean input resistance was increased in TG neurons pretreated with Lgmn compared with Lgmn vehicle, but there was no statistically significant difference (Lgmn: $659.3 \pm$ 93.9 $\mathrm{M} \Omega, n=13$; Lgmn vehicle: $526.9 \pm 79.9 \mathrm{M} \Omega ; n=11, t_{(22)}=$ 1.052, $p=0.3443$, unpaired Student's $t$ test). To investigate requirement for activity, we preincubated Lgmn with LI-1 (10 $\mu \mathrm{M}, 10 \mathrm{~min})$ or vehicle. LI-1 prevented the effect of Lgmn on 
A

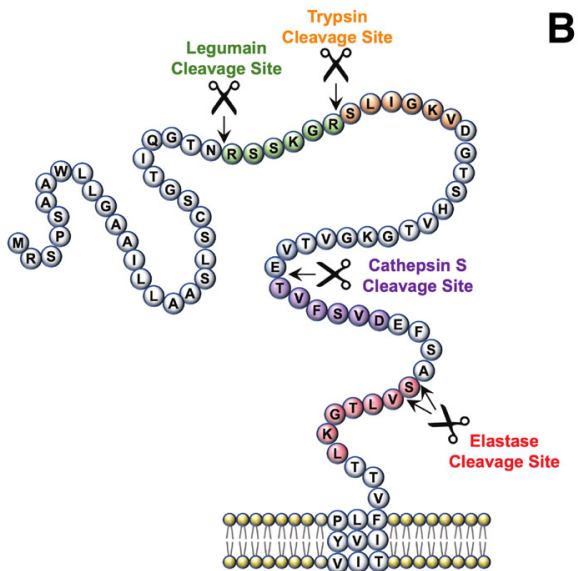

B

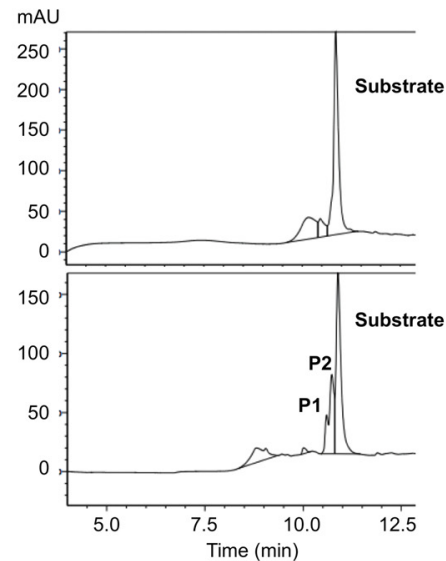

C

SCSGTIQGTNRSSKGRSLIGKVDGTSHVTG (hPAR 2 21-50)

P1: RSSKGRSLIGKVDGTSHVTG (hPAR 2 31-50)

P2: SCSGTIQGTNSCSGTIQGTNRSSKGRSLIGKVDGTSHVTG (ligation hPAR 2 21-30+21-50)
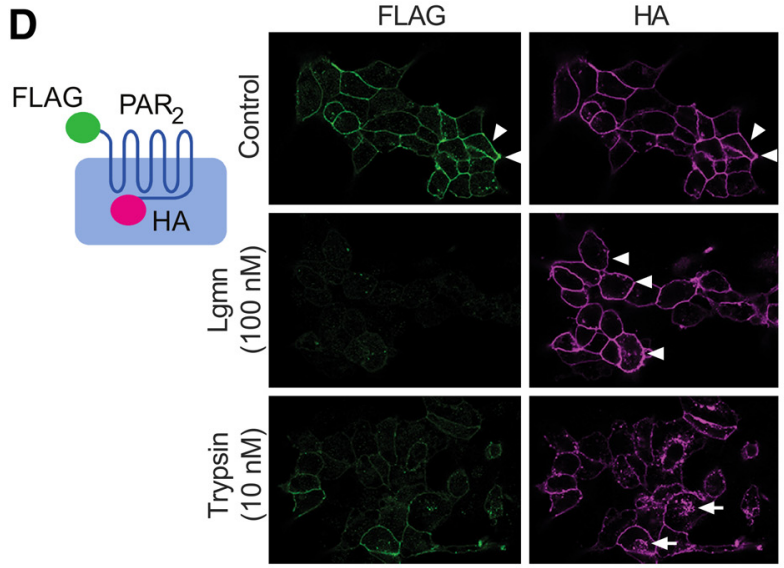

Merge with DAP

HA zoom
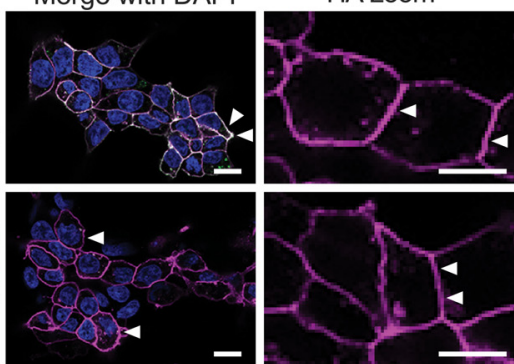

E
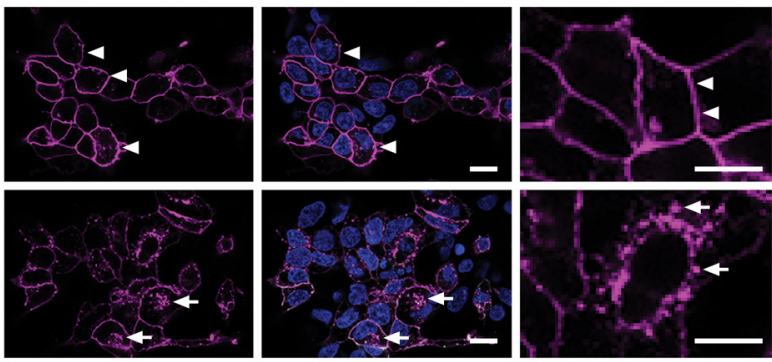

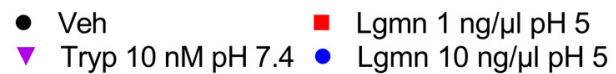
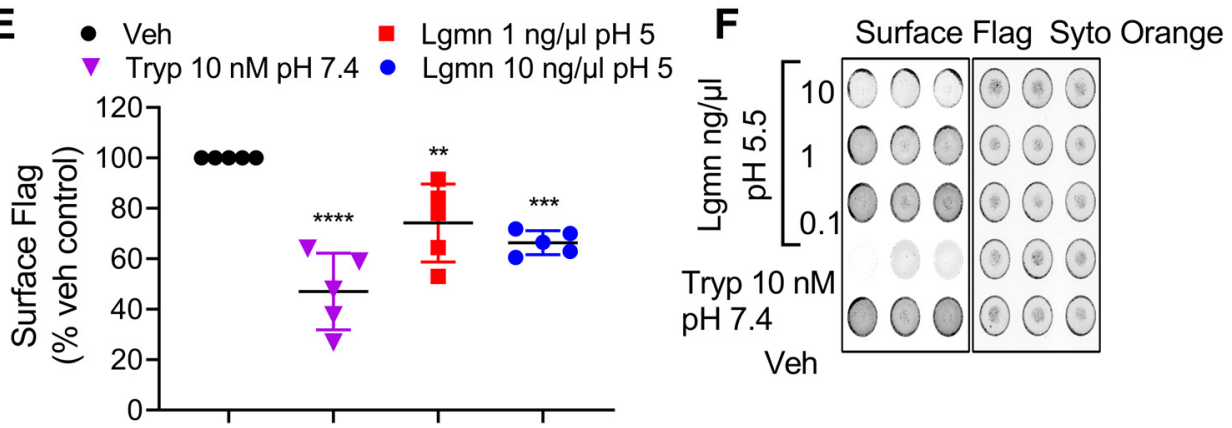

Figure 7. Lgmn cleavage of $P A R_{2} . A$, Lgmn $\mathrm{PAR}_{2}$ cleavage sites and $P A R_{2} N$ terminus indicating known cleavage sites. $B, C, H P L C$ chromatograms $(B)$ and product identification by mass spectrometry $(\boldsymbol{C})$ of degradation of a fragment of $\mathrm{PAR}_{2}\left(\mathrm{hPAR}_{2}{ }^{21-50}\right)$ by Lgmn, showing that Lgmn cleaves $\mathrm{PAR}_{2}$ at $A \mathrm{An}^{30} \downarrow \operatorname{Arg}^{31}$. D, Localization of PAR $\mathrm{R}_{2}$ using antibodies to extracellular N-terminal FLAG and intracellular (-terminal HA epitopes (inset) in HEK-FLAG-PAR - HA cells incubated with vehicle (control), Lgmn, or trypsin. Arrows denote plasma membrane localization; arrowheads denote endosomal localization. Scale bar: $20 \mu \mathrm{m}$. $\boldsymbol{E}, \boldsymbol{F}, 0 \mathrm{n}$-cell Western showing that trypsin and Lgmn remove the extracellular Nterminal FLAG epitope from HEK-FLAG-PAR - HA cells. $\boldsymbol{E}$, Quantification of triplicate observations from $n=5$ individual experiments $\left(F_{(5,22)}=16.03,{ }^{* *} p=0.0034, \mathrm{Lgmn} 1 \mathrm{ng} / \mu \mathrm{l}\right.$ compared with vehicle, ${ }^{* * *} p=0.0002$, Lgmn $100 \mathrm{ng} / \mu \mathrm{g}$ compared with vehicle, ${ }^{* * * *} p=2.5 \mathrm{E}-7$ trypsin compared with vehicle, one-way ANOVA with Dunnett's test, $\left.n=5\right)$. $\boldsymbol{F}$, Representative images of FLAG immunoreactivity and Syto Orange stain.

rheobase (Fig. 6A,B). To investigate the contribution of $\mathrm{PAR}_{2}$, we analyzed Lgmn-induced hyperexcitability in TG neurons from $\mathrm{Par}_{2}{ }^{-1-}$ mice. Lgmn $(20 \mathrm{ng} / \mathrm{ml}, 10 \mathrm{~min})$ did not affect rheobase of $\mathrm{Par}_{2}{ }^{-1-}$ neurons (Fig. 6C,D).

To evaluate the signaling pathway that mediates effects of Lgmn on excitability, perforated patch-clamp recordings were made from TG neurons pretreated with inhibitors of protein kinase C (PKC; GFX, $1 \mu \mathrm{m}$; Coultrap et al., 1999) or protein kinase A (PKA; PKI-tide, $1 \mu \mathrm{m}$; Ohlstein et al., 1990) for $30 \mathrm{~min}$ at $37^{\circ} \mathrm{C}$ before treatment with Lgmn $(20 \mathrm{ng} / \mathrm{ml})$ or vehicle. GFX and PKI-tide prevented Lgmn-induced hyperexcitability (Fig. 6E). Thus, Lgmn causes hyperexcitability of TG nociceptors through Lgmn enzymatic activity, expression of $\mathrm{PAR}_{2}, \mathrm{PKC}$ activity, and PKA activity.

\section{Lgmn cleaves $\mathrm{PAR}_{2}$}

To determine whether Lgmn can cleave $\mathrm{PAR}_{2}$ and identify the cleavage site, Lgmn (200 nm in acetate buffer, $\mathrm{pH} 4.5$ ) 
Table 2. Masses of $\mathrm{hPAR}_{2} \mathrm{~N}$-terminal peptide cleavage products identified by mass spectrometry

\begin{tabular}{llc}
\hline Peptide & Expected & Found \\
\hline Substrate: & M: 2991.268 & \\
SCSGTIQGTNRSSKGRSLIGKVDGTSHVTG & $(\mathrm{M}+2) / 2: 1496.64$ & 1496.45 \\
& $(\mathrm{M}+3) / 2: 998.10$ & 998.10 \\
& $(\mathrm{M}+4) / 4: 748.83$ & 748.80 \\
Product 1: & $\mathrm{M}: 2042.263$ & \\
RSSKGRSLIGKVDGTSHVTG & $(\mathrm{M}+2) / 2: 1022.14$ & 1022.45 \\
& $(\mathrm{M}+3) / 3: 681.76$ & 681.95 \\
& $(\mathrm{M}+4) / 4: 511.57$ & \\
Product 2: & $\mathrm{M}: 3958.274$ \\
SCSGTIQGTNSCSGTIQGTNRSSKGRSLIGKVDGTSHVTG $\mathrm{H}_{2} \mathrm{O}$ & $(\mathrm{M}+2) / 2: 1980.15$ & \\
& $(\mathrm{M}+3) / 3: 1320.43$ & 1320.10 \\
& $(\mathrm{M}+4) / 4: 990.58$ & 990.40 \\
\hline
\end{tabular}

was incubated with a peptide corresponding to residues 21-50 $\left(S^{21}\right.$ CSGTIQGTNRSSKGRSLIGKVDGTSHVTG $\left.{ }^{50}\right)$ of the extracellular $\mathrm{N}$ terminus of $\mathrm{hPAR}_{2}(200 \mu \mathrm{M})$. Digest was analyzed by HPLC and mass spectrometry. Cleavage products were detected corresponding to $\mathrm{PAR}_{2}{ }^{31-50}$ and $\mathrm{PAR}_{2}{ }^{21-30}$ fused to $\mathrm{PAR}_{2}{ }^{21-50}$ (Fig. 7A-C; Table 2). Thus, Lgmn cleaves the $\mathrm{N}$ terminus of $\mathrm{hPAR}_{2}$ at $\mathrm{Asn}^{30} \downarrow \mathrm{Arg}^{31}$ consistent with its preference for asparagine residues and ability to ligate peptides with C-terminal asparagine residues to free $\mathrm{N}$ termini (Mikula et al., 2017).

To determine whether Lgmn cleaves intact $\mathrm{PAR}_{2}$ at the plasma membrane, $\mathrm{hPAR}_{2}$ with an extracellular FLAG epitope and intracellular HA epitope was expressed in HEK293 cells (Fig. $7 D)$. HEK-FLAG-PAR 2 -HA cells were incubated with Lgmn (100 nm, HBSS pH 5.0), trypsin (10 nm, HBSS pH 7.4), or vehicle (buffer control). FLAG and HA were localized by immunofluorescence and confocal microscopy. In vehicle-treated cells, FLAG and HA colocalized at the plasma membrane (Fig. 7D). After incubation with Lgmn, FLAG was depleted from the plasma membrane whereas HA was retained at the plasma membrane, consistent with $\mathrm{PAR}_{2}$ cleavage and removal of the extracellular FLAG epitope. After incubation with trypsin, FLAG was depleted from the plasma membrane, and HA was detected within endosomes, consistent with $\mathrm{PAR}_{2}$ cleavage and endocytosis (Böhm et al., 1996a).

On-cell Western was used to quantify removal of the FLAG epitope. In Lgmn incubated cells ( 1 or $10 \mathrm{ng} / \mu \mathrm{l}$, MES-HBSS $\mathrm{pH}$ $\left.5.0,30 \mathrm{~min}, 37^{\circ} \mathrm{C}\right)$, FLAG immunoreactivity was reduced $26 \pm 7 \%(1 \mathrm{ng} / \mu \mathrm{l})$ or $34 \pm 2 \%(10 \mathrm{ng} / \mu \mathrm{l})$ versus vehicle-treated cells (Fig. 7E,F). After trypsin incubation (10 nм, HBSS pH 7.4, $30 \mathrm{~min}, 37^{\circ} \mathrm{C}$ ), FLAG immunoreactivity was reduced $53 \pm 7 \%$ versus vehicle-treated cells. Nuclear stain (Syto Orange) confirmed that proteases did not remove cells from the plate (Fig. $7 F$ ).

Thus, Lgmn can cleave intact $\mathrm{PAR}_{2}$ at the surface of HEK cells and remove the extracellular FLAG epitope. Lgmn cleaves $\mathrm{PAR}_{2}$ at $\mathrm{Asn}^{30} \downarrow \mathrm{Arg}^{31}$, proximal to the trypsin cleave site $\left(\mathrm{Arg}^{36} \downarrow\right.$ $\left.\mathrm{Ser}^{37}\right)$. Lgmn does not evoke endocytosis of $\mathrm{PAR}_{2}$.

\section{Lgmn activity and Lgmn-induced $\mathrm{Ca}^{2+}$ signaling are $\mathrm{pH}$ dependent}

Trypsin, tryptase, and kallikreins cleave $\mathrm{PAR}_{2}$ at $\mathrm{Arg}^{36} \downarrow \mathrm{Ser}^{37}$ and induce coupling to $\mathrm{G}_{\alpha \mathrm{q}}$ and mobilization of intracellular $\mathrm{Ca}^{2+}$ (Böhm et al., 1996a; Corvera et al., 1999; Oikonomopoulou et al., 2006). To examine whether Lgmn can mobilize $\mathrm{Ca}^{2+}$, HEK-
FLAG-PAR 2 -HA cells were challenged with Lgmn ( 1 or $10 \mathrm{ng} / \mu \mathrm{l}$, MES-HBSS pH 5.0, 5.5, 6.0 or HBSS pH 7.4), trypsin (10 nм, HBSS pH 7.4), or vehicle (buffer control). Change in intracellular $\mathrm{Ca}^{2+}$ was measured using fura-2 AM. Trypsin increased $\mathrm{Ca}^{2+}$, reflected by increased F340/380 nm emission, which rapidly declined toward basal (Fig. 8A). At $\mathrm{pH} 7.4,10 \mathrm{ng} / \mu \mathrm{l} \mathrm{Lgmn}$ induced a small increase in $\mathrm{Ca}^{2+}$, whereas $1 \mathrm{ng} / \mu \mathrm{l}$ Lgmn did not elicit a $\mathrm{Ca}^{2+}$ response (Fig. 8A). At a lower $\mathrm{pH}$ of 5.0, 1 and $10 \mathrm{ng} / \mu \mathrm{l}$ Lgmn caused sustained and concentration-dependent increases in $\mathrm{Ca}^{2+}$ (Fig. 8B,E). At pH 5.0 and 5.5, $10 \mathrm{ng} / \mu \mathrm{l} \mathrm{Lgmn}$ increased $\mathrm{Ca}^{2+}$, compared with $\mathrm{pH} 6.0$ and 7.4 (Fig. 8C,D); however, at $\mathrm{pH} 5,1 \mathrm{ng} / \mu \mathrm{l} \mathrm{Lgmn}$ increased $\mathrm{Ca}^{2+}$ compared with $\mathrm{pH}$ 5.5 and 6.0 (Fig. 8E,F). Lgmn activity assays confirmed the acidic $\mathrm{pH}$ optimum of Lgmn, which was active at $\mathrm{pH} 5.0$ and 5.5 but not $\mathrm{pH}>6.0$ (Fig. $8 G$ ). Lgmn increased $\mathrm{Ca}^{2+}$, in the absence of extracellular $\mathrm{Ca}^{2+}$, indicating intracellular mobilization (Fig. $8 H)$. The Lgmn inhibitors, QDD100531 ( $1 \mu \mathrm{M})$ and QD123427 $(100 \mathrm{nM})$, prevented Lgmn-evoked $(1 \mathrm{ng} / \mu \mathrm{l}) \mathrm{Ca}^{2+}$ signals (Fig. $8 I, J)$, and caused concentration-dependent inhibition of activity (Fig. 8K; Ness et al., 2015).

\section{Lgmn induces $\mathrm{Ca}^{2+}$ signaling through $\mathrm{PAR}_{2}$}

To determine whether Lgmn induces $\mathrm{Ca}^{2+}$ signaling through $\mathrm{PAR}_{2}$, we used specific antagonists for $\mathrm{PAR}_{2}$ and cells genetically deleted for $\mathrm{PAR}_{2} . \mathrm{PAR}_{2}$ antagonists, I-343 and GB88 (10 $\mu \mathrm{M}$; Farmer, 2013; Lieu et al., 2016; Jimenez-Vargas et al., 2018) abolished Lgmn-stimulated ( 1 and $10 \mathrm{ng} / \mu \mathrm{l}) \mathrm{Ca}^{2+}$ responses (Fig. $9 A-C)$. I-343 and GB88 did not inhibit the enzymatic activity of Lgmn $(1 \mathrm{ng} / \mu \mathrm{l})$, which was slightly increased in the presence of these antagonists (Fig. 9D). To determine whether Lgmn induced a $\mathrm{Ca}^{2+}$ increase through $\mathrm{PAR}_{1}$, we used the specific $\mathrm{PAR}_{1}$ antagonist SCH79797 (Ahn et al., 2000). SCH79797 (200 nM) did not alter Lgmn-induced $\mathrm{Ca}^{2+}$ responses (Fig. 9E,F). To confirm the pharmacologic evidence that $\mathrm{PAR}_{2}$, and not $\mathrm{PAR}_{1}$, mediated Lgmn-evoked $\mathrm{Ca}^{2+}$ signals, $\mathrm{PAR}_{2}$ or $\mathrm{PAR}_{1}$ was deleted from HEK293 cells using CRISPR/Cas9 (Ungefroren et al., 2017). In $\mathrm{PAR}_{2}-\mathrm{KO}$ cells, the $\mathrm{PAR}_{2}$ selective agonist 2-FuroylLIGRLO- $\mathrm{NH}_{2}$ did not increase $\mathrm{Ca}^{2+}$ (Fig. 9G); however, the $\mathrm{PAR}_{1}$ selective agonist TFLLR-NH $\mathrm{N}_{2}$ increased $\mathrm{Ca}^{2+}$ in $\mathrm{PAR}_{2}-\mathrm{KO}$ cells (Fig. 9H). In $\mathrm{PAR}_{1}-\mathrm{KO}$ cells, TFLLR-NH $\mathrm{N}_{2}$ did not increase $\mathrm{Ca}^{2+}$ except at a high concentration (10 $\mu \mathrm{M}$; Fig. 9I), whereas 2Furoyl-LIGRLO-NH$H_{2}$ increased $\mathrm{Ca}^{2+}$ in $\mathrm{PAR}_{1}-\mathrm{KO}$ cells (Fig. 9J). Lgmn $(10 \mathrm{ng} / \mu \mathrm{l})$ mobilized $\mathrm{Ca}^{2+}$ in $\mathrm{PAR}_{1}-\mathrm{KO}$ but not $\mathrm{PAR}_{2}-\mathrm{KO}$ cells (Fig. $9 K$ ).

To confirm that Lgmn activates $\mathrm{PAR}_{2}$ by cleavage at the $\mathrm{Asn}^{30} \downarrow \mathrm{Arg}^{31}$ site, we generated a mutant receptor in which the $\mathrm{Asn}^{30}$ residue was mutated to $\mathrm{Ala}$, which would not be recognized by Lgmn. $\mathrm{PAR}_{2}-\Delta \mathrm{N} 30 \mathrm{~A}$ was transfected into $\mathrm{PAR}_{2}-\mathrm{KO}$ HEK cells. 2-Furoyl-LIGRLO- $\mathrm{NH}_{2}(10 \mu \mathrm{M})$ robustly increased $\mathrm{Ca}^{2+}$ in HEK-PAR ${ }_{2} \Delta \mathrm{N} 30 \mathrm{~A}$ cells, whereas Lgmn $(10 \mathrm{ng} / \mu \mathrm{l}) \mathrm{had}$ no effect (Fig. 9L). To determine whether Lgmn activates $\mathrm{PAR}_{2}$ by exposure of a tethered ligand, we synthesized a hexapeptide, $\mathrm{R}^{31} \mathrm{SSKGR}^{36}$, corresponding to a potential tethered ligand revealed by Lgmn cleavage of $\mathrm{PAR}_{2}$ at the $\mathrm{Asn}^{30} \downarrow \mathrm{Arg}^{31}$ site. However, $\mathrm{R}^{31} \mathrm{SSKGR}^{36}(10 \mu \mathrm{M}$ to $0.01 \mathrm{~nm})$ did not alter $\mathrm{Ca}^{2+}$ in HEK-PAR 2 cells (Fig. 9M). These data confirm that the Lgmndriven $\mathrm{Ca}^{2+}$ response is $\mathrm{PAR}_{2}$ dependent but does not involve exposure of a tethered ligand domain.

Lgmn desensitizes $\mathrm{PAR}_{2}$, but does not induce an association between $\mathrm{PAR}_{2}$ and $\boldsymbol{\beta}$-arrestin-1

Processes that terminate $\mathrm{PAR}_{2}$ signaling at the plasma membrane include $\beta$-arrestin-mediated desensitization of $\mathrm{PAR}_{2}$, 

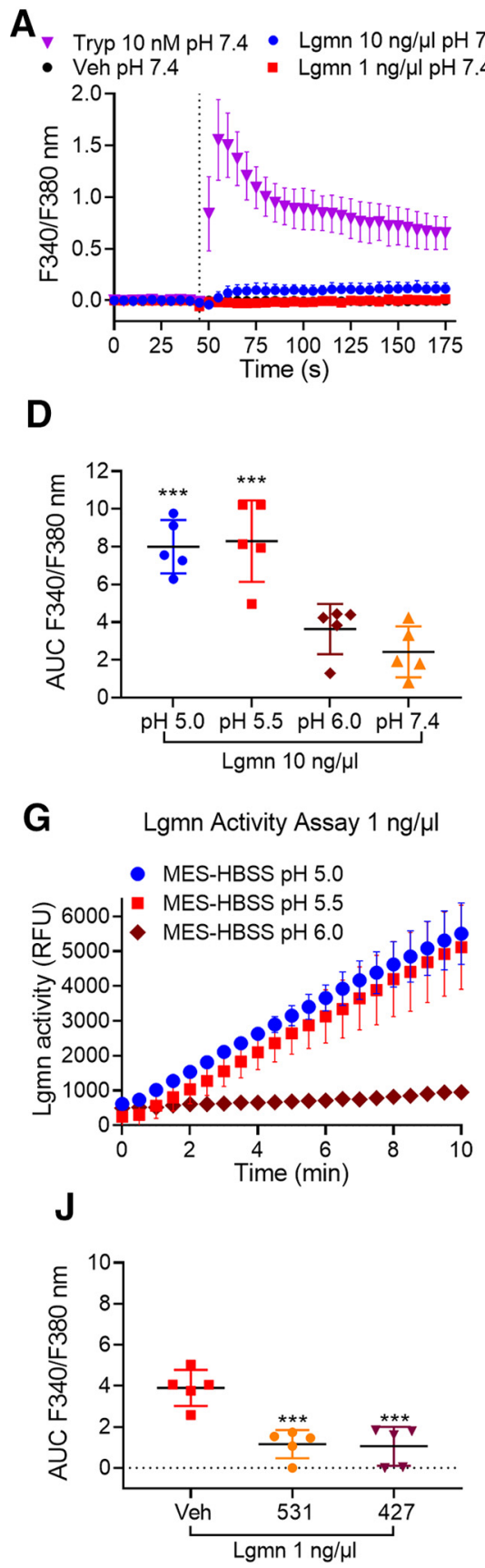

B

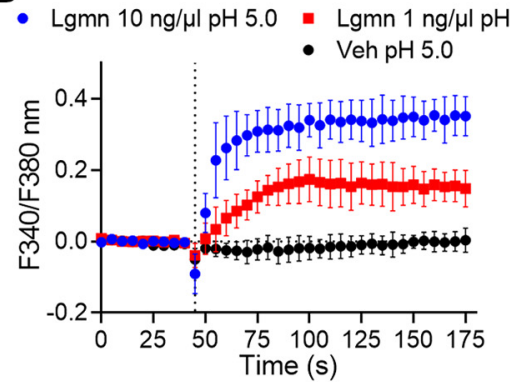

E.

- Lgmn $1 \mathrm{ng} / \mathrm{\mu l} \mathrm{pH} 5.0$ - Lgmn $1 \mathrm{ng} / \mathrm{H} \mathrm{pH} 5.5$ - Lgmn $1 \mathrm{ng} / \mathrm{\mu l} \mathrm{pH} 6.0$

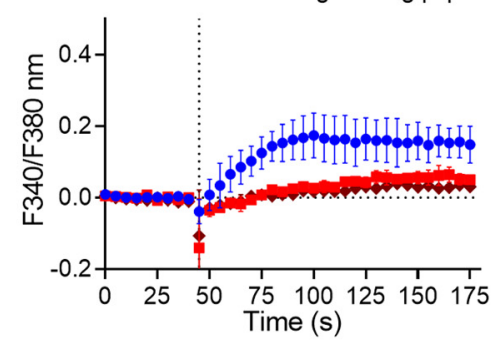

H $\mathrm{Ca}^{2+}$ Free HBSS
- Lgmn $10 \mathrm{ng} / \mu \mathrm{pH} 5.0 \quad$ Lgmn $1 \mathrm{ng} / \mu \mathrm{pH} 5.0$

- Veh pH5.0

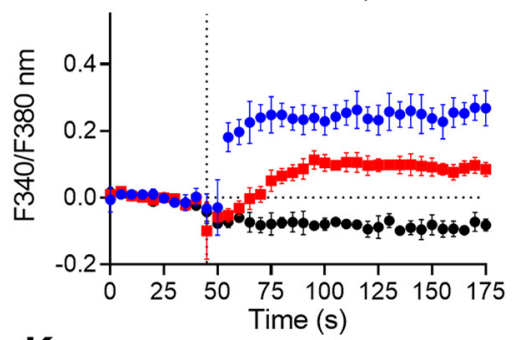

K

Lgmn Activity Assay $1 \mathrm{ng} / \mu \mathrm{l}$

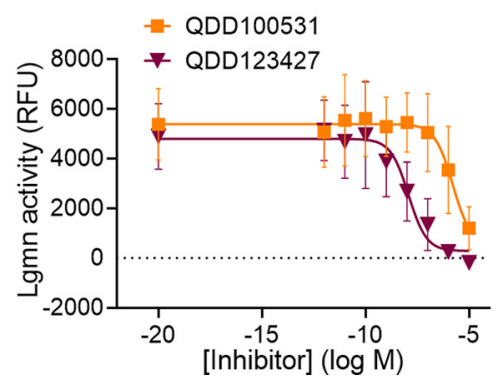

C

- Lgmn $10 \mathrm{ng} / \mu \mathrm{l} \mathrm{pH} 5.0$ Lgmn $10 \mathrm{ng} / \mu \mathrm{l} \mathrm{pH} 6.0$

- Lgmn $10 \mathrm{ng} / \mu \mathrm{lpH} 5.5 \mathrm{v}$ Lgmn $10 \mathrm{ng} / \mu \mathrm{lpH} 7.4$

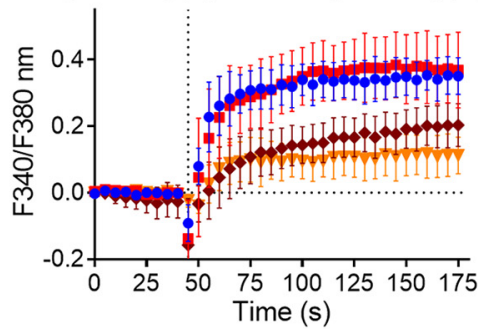

$\mathbf{F}$

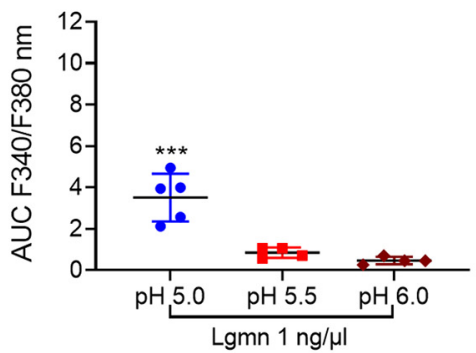

I

- Lgmn $1 \mathrm{ng} / \mu \mathrm{l}$ - Lgmn $1 \mathrm{ng} / \mu \mathrm{l}+531$

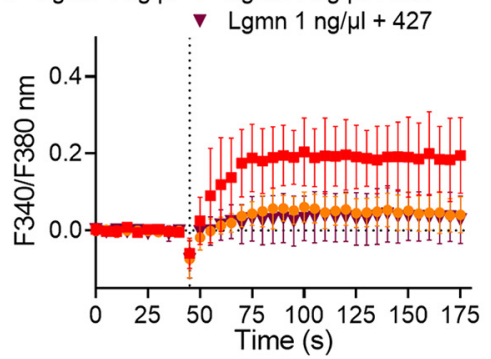

Figure 8. $\mathrm{pH}$ dependence of $\mathrm{Lgmn}$ activity and stimulation of $\mathrm{Ca}^{2+}$ signaling. Time course $(\boldsymbol{A}-\boldsymbol{C})$ and area under curve $(\mathrm{AUC} ; \boldsymbol{D})$ of trypsin-evoked and $\mathrm{Lgmn}$-evoked $\mathrm{Ca}^{2+}$ signaling in HEKFLAG-PAR 2 -HA cells at pH 7.4, 6.0, 5.5, and $5.0\left(F_{(3,16)}=17.5{ }^{* * *} p=0.003\right.$, pH 5.0 compared with pH 7.4, ${ }^{* * *} p=0.0001$, pH 5.5 compared with pH 7.4, one-way ANOVA with Tukey's test, $n=5) . \boldsymbol{E}, \boldsymbol{F}$, Time course $(\boldsymbol{E})$ and AUC $(\boldsymbol{F})$ of $\mathrm{Lgmn}(1 \mathrm{ng} / \mu \mathrm{l})$-evoked $\mathrm{Ca}^{2+}$ signaling in HEK-FLAG-PAR 2 -HA cells at pH 6.0, 5.5, and $5.0\left(F_{(2,10)}=22.68,{ }^{* * *} p=0.0009\right.$ for pH 5.0 compared with $\mathrm{pH} 5.5$ and ${ }^{* * *} p=0.0003$ for pH 5.0 compared with pH 6.0, one-way ANOVA with Tukey's test, $n=5$ ). $\boldsymbol{G}$, Lgmn activity assays at pH 5.0, 5.5, and 6.0. $\boldsymbol{H}$, Effects of depletion of extracellular $\mathrm{Ca}^{2+}$ on Lgmn responses. $I$, J, Time course $(I)$ and AUC $(J)$ of the effects of the Lgmn inhibitors QDD100531 (531) and QD123427 $(427)$ on $\operatorname{Lgmn}^{2} \mathrm{Ca}^{2+}$ signals $\left(F_{(2,12)}=22.32\right.$, ${ }^{* * *} p=0.0002$ for 531 and ${ }^{* * *} p=0.0002$ for 427 compared with vehicle, one-way ANOVA with Tukey's test, $n=5$ ). $\boldsymbol{K}$, Lgmn activity assay in the presence of graded concentrations of Lgmn inhibitors QDD100531 and QDD123427 (pH 5.0).

$\mathrm{PAR}_{2}$ cleavage and removal of activation sites and tethered ligand domains, and $\mathrm{PAR}_{2}$ endocytosis (Böhm et al., 1996a; Déry et al., 1999; DeWire et al., 2007). Since Lgmn cleaves $\mathrm{PAR}_{2}$ proximal to the trypsin site, subsequent inhibition of trypsin signaling would likely reflect $\mathrm{PAR}_{2}$ desensitization. To examine desensitization, HEK-FLAG-PAR 2 -HA cells were incubated with Lgmn ( 1 or $10 \mathrm{ng} / \mu \mathrm{l}$, MES-HBSS pH 5.0), trypsin (10 nm, HBSS pH 7.4), or vehicle (buffer control; Fig. 10A). Cells were washed and recovered in HBSS pH 7.4 for 20 min and then challenged with trypsin $(10 \mathrm{~nm})$. In cells preincubated with vehicle, trypsin challenge at $30 \mathrm{~min}$ robustly increased $\mathrm{Ca}^{2+}$ (Fig. 10B,C). Initial challenge with trypsin also increased $\mathrm{Ca}^{2+}$, but response to a second challenge at $30 \mathrm{~min}$ was reduced by $53.7 \pm 6.3 \%$ versus the response in vehicle-treated cells, consistent with desensitization and endocytosis of $\mathrm{PAR}_{2}$. Initial challenge with $\operatorname{Lgmn}(10 \mathrm{ng} / \mu \mathrm{l})$ slightly increased $\mathrm{Ca}^{2+}$, but the response to a second challenge at 

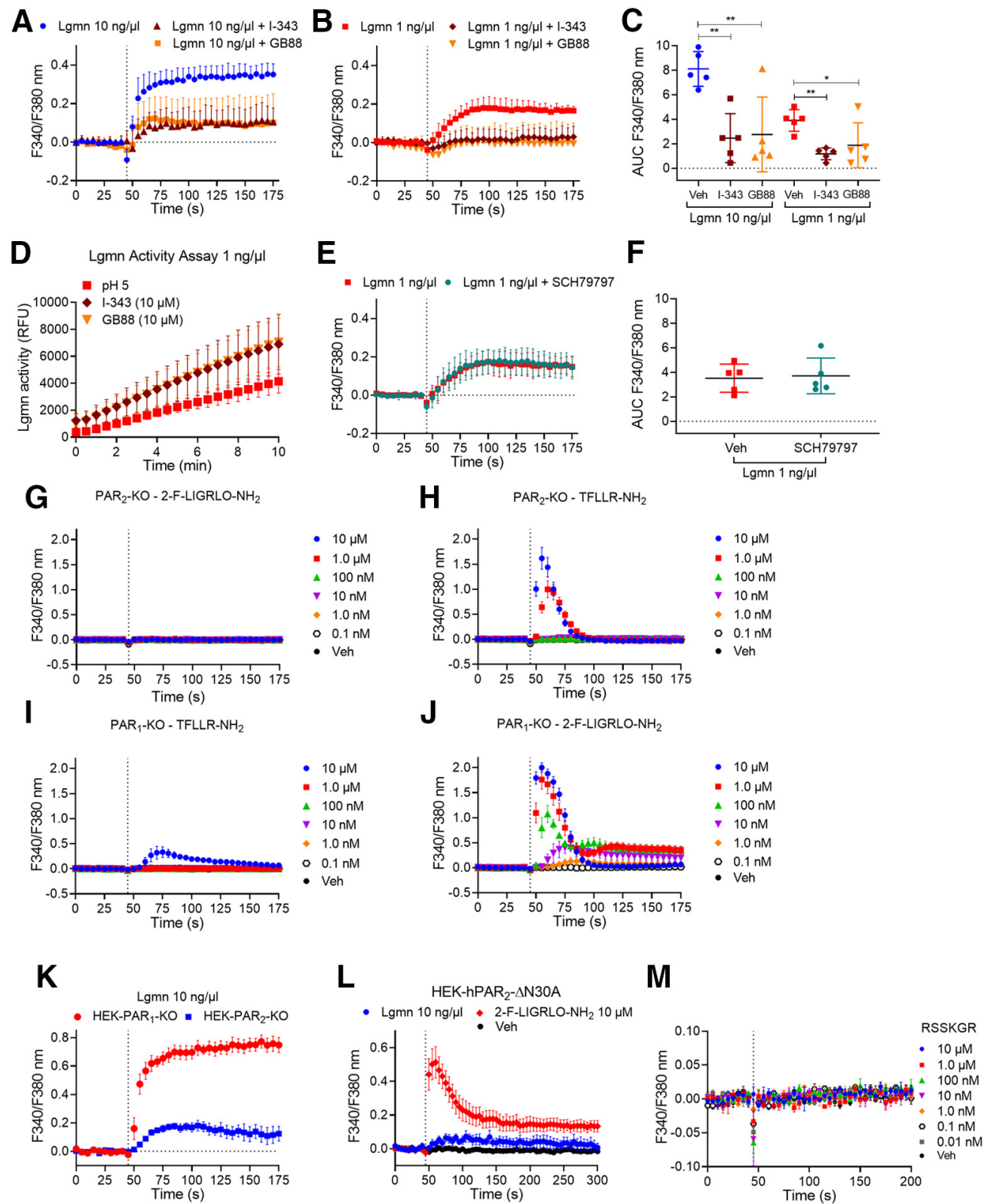

Figure 9. Lgmn signals through $\mathrm{PAR}_{2}$. $\boldsymbol{A}-\boldsymbol{C}$, Time course $(\boldsymbol{A}, \boldsymbol{B})$ and area under curve $(\boldsymbol{C})$ of the effects of the $\mathrm{PAR}_{2}$ antagonists $\mathrm{I}-343$ and $G B 88$ on $L g m n \mathrm{Ca}^{2+}$ signals $\left(F_{(2,12)}=9.89\right.$ for Lgmn $10 \mathrm{ng} / \mu \mathrm{l}$ with ${ }^{* *} p=0.0036$ for I-343 and ${ }^{* *} p=0.0052$ for GB88 compared with vehicle, $F_{(2,12)}=6.84$ for Lgmn $1 \mathrm{ng} / \mu \mathrm{l}$ with ${ }^{* *} p=0.0073$ for I-343 and ${ }^{*} p=0.0384$ for GB88 compared with vehicle, one-way ANOVA with Tukey's test, $n=5$ ). $\boldsymbol{D}$, Lgmn activity assays in the presence of the PAR antagonists I-343 and GB88 (pH 5.0). Triplicate observations from $n=5$ indi-

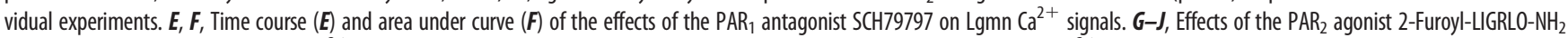
and the PAR ${ }_{1}$ agonist TFLLR-NH ${ }_{2}$ on $\mathrm{Ca}^{2+}$ signals in PAR $-\mathrm{KO}(\boldsymbol{G}, \boldsymbol{H})$ and PAR 1 -KO HEK293 $(\boldsymbol{I}, \boldsymbol{J})$ cells. $\boldsymbol{K}$, Time course of Lgmn $\mathrm{Ca}^{2+}$ signals in HEK-PAR - KO and HEK-PAR ${ }_{2}-K_{0}$ cells. $\boldsymbol{L}$, Time course of Lgmn $\mathrm{Ca}^{2+}$ signals in HEK-PAR $\triangle$ RR3OA cells. $\boldsymbol{M}$, Effects of potential PAR activating peptide $\mathrm{R}^{31} \mathrm{SSKGR}^{36} \mathrm{Ca}^{2+}$ signaling in HEK-FLAG-PAR $\mathrm{R}_{2}-\mathrm{HA}_{\mathrm{A}}$ cells.

30 min was reduced by $49.9 \pm 6.9 \%$ versus response in vehicletreated cells, consistent with desensitization of $\mathrm{PAR}_{2}$.

Given that Lgmn desensitizes $\mathrm{PAR}_{2}$, we sought to determine whether Lgmn recruits $\beta$-arrestin- 1 to $\mathrm{PAR}_{2}$. After trypsin cleavage, $\mathrm{PAR}_{2}$ becomes phosphorylated by GPCR kinases and interacts with $\beta$-arrestins, which mediate desensitization and endocytosis (Corvera et al., 1999). However, after cathepsin S or elastase cleavage, $\mathrm{PAR}_{2}$ neither recruits $\beta$-arrestins nor induces endocytosis (Zhao et al., 2014, 2015). We showed that Lgmn does not induce $\mathrm{PAR}_{2}$ endocytosis (Fig. $7 D$ ). It is unknown whether $\mathrm{PAR}_{2}$ associates with $\beta$-arrestin-1 following Lgmn cleavage. Thus, we examined BRET between $\mathrm{PAR}_{2}$-Rluc8 and $\beta$-arrestin-1-YFP following treatment with Lgmn. Trypsin
(10 nM), but not Lgmn (1 or $10 \mathrm{ng} / \mu \mathrm{l})$, stimulated $\mathrm{PAR}_{2}$ Rluc8/ $\beta$-arrestin-1-YFP BRET (Fig. 10D,E). These results accord with the inability of Lgmn to evoke $\mathrm{PAR}_{2}$ endocytosis.

\section{Lgmn activates $\mathrm{PAR}_{2}$-mediated cAMP formation and activation of PKD and ERK in HEK293 cells}

After activation by trypsin, $\mathrm{PAR}_{2}$ couples to $\mathrm{G}_{\alpha \mathrm{q}}$, leading to mobilization of intracellular $\mathrm{Ca}^{2+}$, generation of cAMP, and activation of ERK and PKD (DeFea et al., 2000; Amadesi et al., 2009). ERK contributes to sensitization of nociceptors (Ji et al., 1999), and $\mathrm{PKD}$ promotes mobilization of $\mathrm{PAR}_{2}$ from Golgi and recovery of responses to extracellular proteases (Amadesi et al., 2009; Zhao et al., 2019). To examine whether Lgmn-activated $\mathrm{PAR}_{2}$ 
A
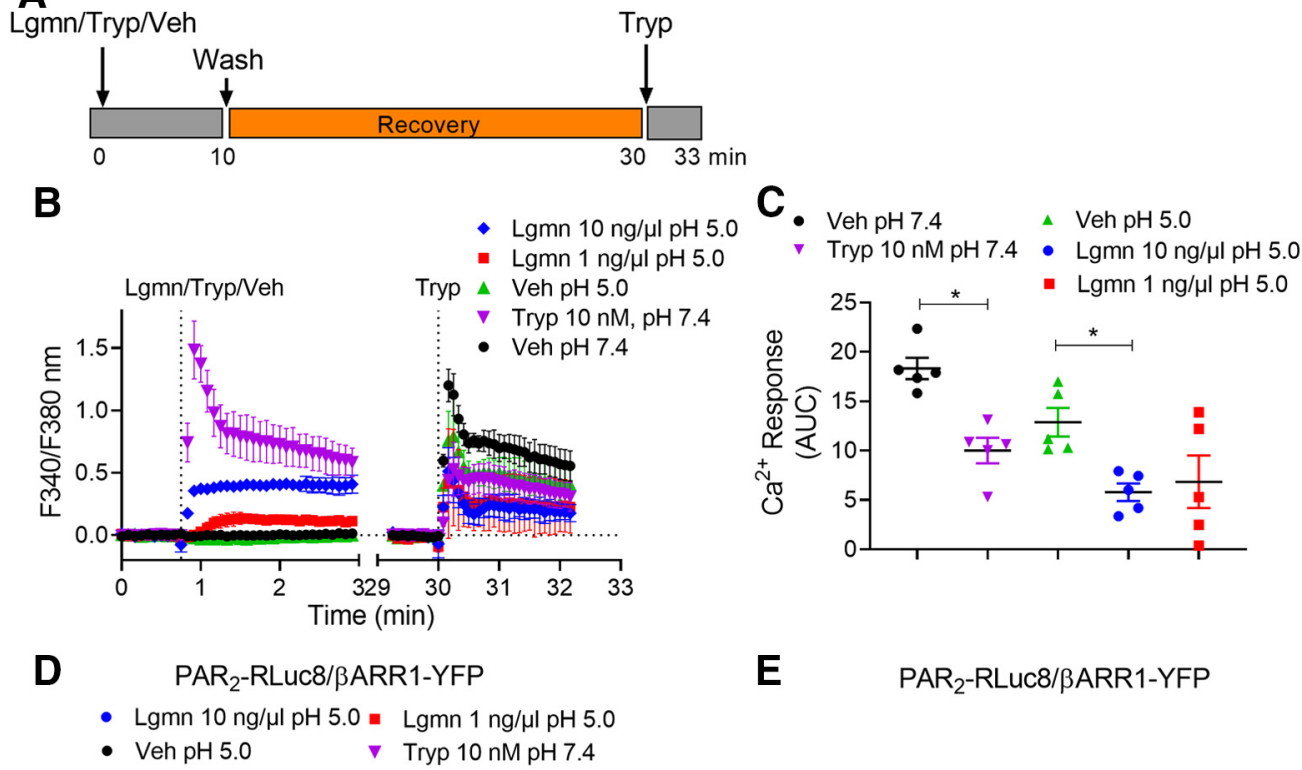

E $\quad$ PAR $_{2}$-RLuC8/ßARR1-YFP
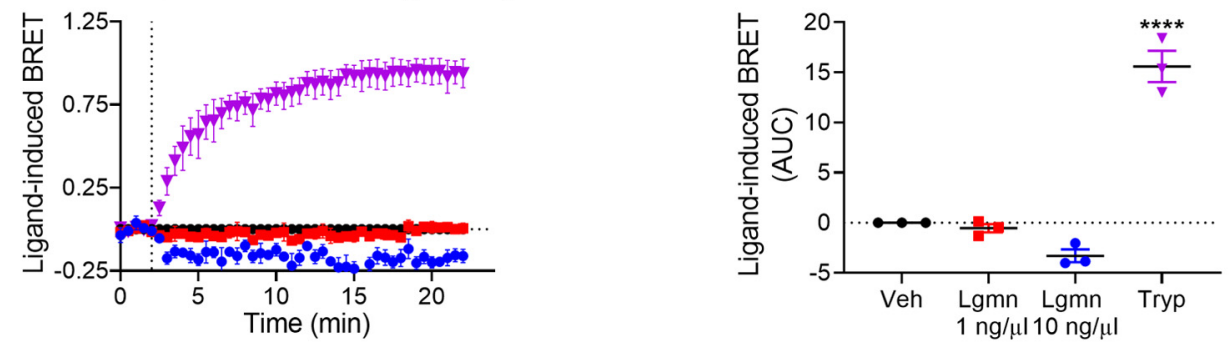

Figure 10. Lgmn desensitization of $\mathrm{PAR}_{2} \mathrm{Ca}^{2+}$ signaling and recruitment of $\beta$-arrestin-1. A, HEK-FLAG-PAR - HA cells were exposed to trypsin or Lgmn for 10 min, washed, and then challenged with trypsin $20 \mathrm{~min}$ after washing. $\boldsymbol{B}$, Time course of $\mathrm{Ca}^{2+}$ signaling. $\boldsymbol{C}$, Recovery of trypsin responses [area under curve (AUC) from $\boldsymbol{B}$ ] in cells pretreated with vehicle, trypsin, or Lgmn $\left(F_{(4,20)}=1.61,{ }^{*} p=0.0116\right.$ for trypsin, and ${ }^{*} p=0.0372$ for Lgmn $10 \mathrm{ng} / \mu \mathrm{l}$ compared with vehicle, one-way ANOVA with Tukey's test $\left.n=5\right)$. D, E, BRET assays of recruitment of $\beta$-arrestin-1 to $\mathrm{PAR}_{2}$. D, Time courses. $\boldsymbol{E}$, AUC $\left(F_{(3,8)}=96.95,{ }^{* * * *} p=1.25 \mathrm{E}-6\right.$ for trypsin versus vehicle, one-way ANOVA with Tukey's test, $\left.n=5\right)$. All assays were done in triplicate.

couples to a similar range of downstream effectors, we expressed FRET biosensors of cytosolic cAMP (Cyto-Epac), cytosolic PKD (Cyto-DKAR), and cytosolic ERK (Cyto-EKAR) in HEK-FLAG$\mathrm{PAR}_{2}$-HA cells. Lgmn caused concentration-dependent activation of cAMP (Fig. 11A,B), PKD (Fig. 11C,D), and ERK (Fig. $11 E, F)$ within the cytosol. cAMP and $\mathrm{PKD}$ responses were robust; however, the ERK response was small and detected only after treatment with a higher Lgmn concentration.

\section{Discussion}

We report that Lgmn is secreted from OSCC cells and is robustly and reproducibly activated in human and mouse OSCCs compared with normal mucosa. Under acidic conditions, Lgmn cleaves and activates $\mathrm{PAR}_{2}$ by biased mechanisms to evoke sustained hyperexcitability of nociceptors. We confirmed that $\mathrm{PAR}_{2}$ and Lgmn contribute to OSCC pain in OSCC mouse models that recapitulate the progression of OSCC observed in humans; genes for Lgmn and $\mathrm{PAR}_{2}$ on nociceptors were deleted in these mice. Lgmn contributes to cancer hallmarks including proliferation, invasion, and metastasis (Murthy et al., 2005; Vasiljeva et al., 2006; Li et al., 2013; Ohno et al., 2013; Edgington-Mitchell et al., 2015). While Lgmn has been reported to produce bone cancer pain through neurotrophin receptors (Yao et al., 2017), the role of the Lgmn/PAR 2 axis has not been described and could be therapeutically exploited.

The mechanism responsible for Lgmn activation in oral cancer is unresolved. Lgmn is synthesized as pro-Lgmn and traffics through the endoplasmic reticulum and Golgi (Dall and Brandstetter, 2016). Lgmn is packaged and activated in the acidic environment of lysosomes (Dall and Brandstetter, 2016). At $\mathrm{pH}>6.0$, acidic residues unfold and lose proteolytic activity. $\mathrm{pH}$ in cancers varies (5.4-6.7; Meyer et al., 1948; Vaupel et al., 1981; Newell et al., 1993; Gillies et al., 1994); the Lgmn activation mechanism remains obscure (Dall and Brandstetter, 2012). Exosomes released from OSCC might exhibit a $\mathrm{pH}$ low enough to activate Lgmn. A single report reveals acidic exosomes in cancer patients (Logozzi et al., 2019). Cells from human OSCCs, including the cell line used in this study (HSC-3), secrete exosomes (Dayan et al., 2012; Li et al., 2019). Stabilization between a RGD motif in the catalytic domain and the integrin $\alpha_{\mathrm{v}} \beta_{3}$ might also activate Lgmn at a higher $\mathrm{pH}$ (Liu et al., 2012).

We demonstrated that Lgmn causes cancer-associated nociception through $\mathrm{PAR}_{2}$ activation on $\mathrm{Na}_{\mathrm{v}} 1$.8-expressing neurons. While all nociceptors express $N a_{v} 1.8$, some non-nociceptors, including low-threshold mechanoreceptors that mediate touch sensation, also express $N a_{v} 1.8$ (Shields et al., 2012). Since Lgmn activates cathepsins (Edgington-Mitchell et al., 2016), which can also activate $\mathrm{PAR}_{2}$ (Zhao et al., 2014), it is possible that Lgmn activates $\mathrm{PAR}_{2}$ directly or indirectly (Edgington-Mitchell et al., 2016). However, we found that Lgmn directly cleaves a fragment of $\mathrm{hPAR}_{2}$ at a unique $\mathrm{Asn}^{30} \downarrow \mathrm{Arg}^{31}$ site, consistent with known Lgmn selectivity. Site mutation prevented Lgmn-evoked signaling, confirming this mechanism of proteolytic activation. Lgmn evoked hypersensitivity of TG neurons from WT mice 
A

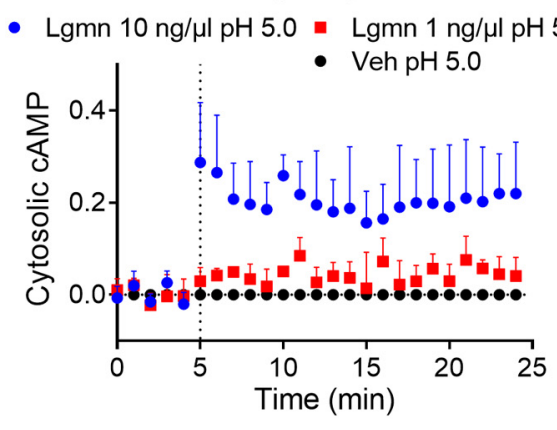

C

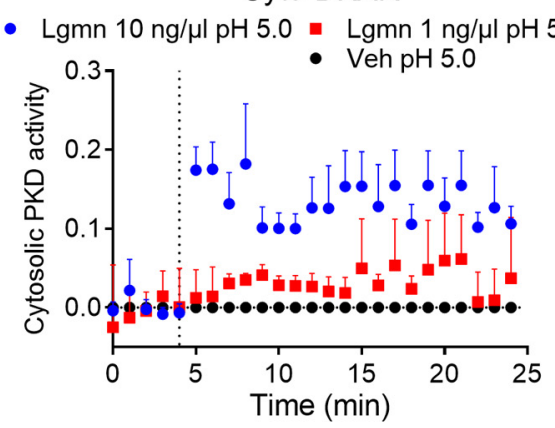

E

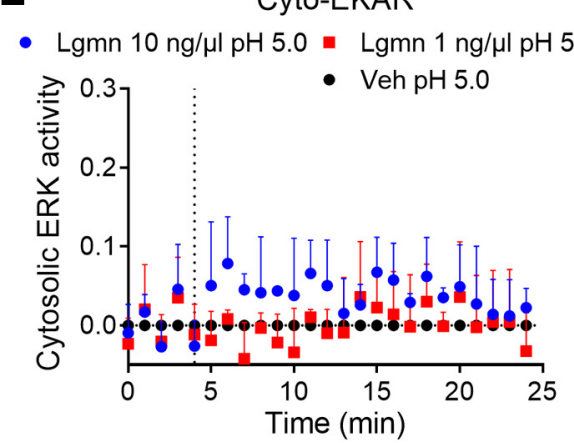

B

Cyto-Epac

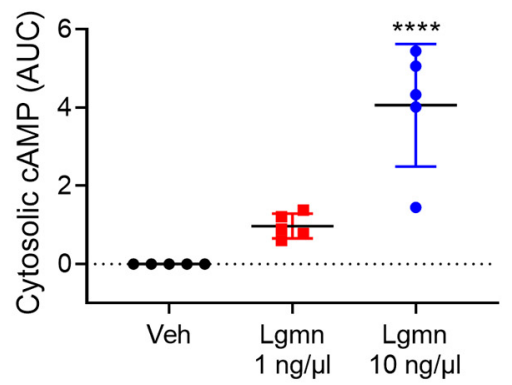

D Cyto-DKAR

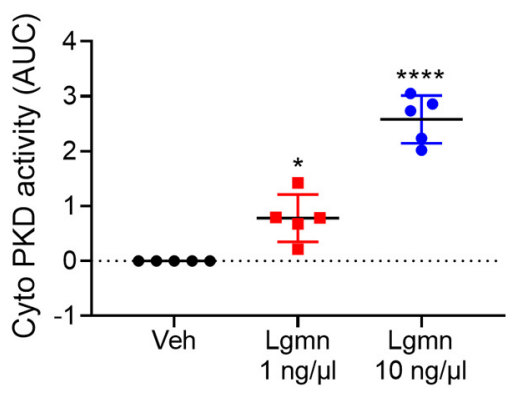

$\mathbf{F}$

Cyto-EKAR

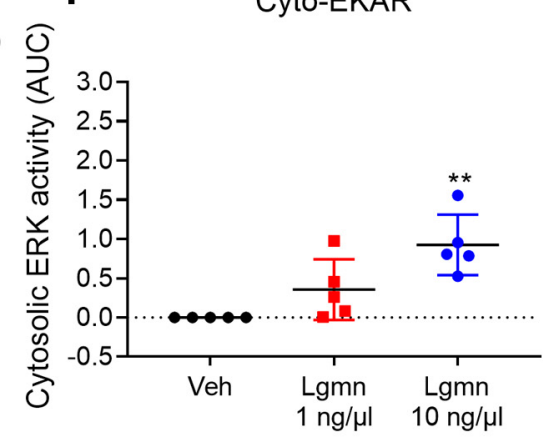

Figure 11. Lgmn activation of CAMP, PKD and ERK signaling and recruitment of $\beta$-arrestin-1. $\boldsymbol{A}-\boldsymbol{F}$, FRET assays of cytosolic CAMP $(\boldsymbol{A}, \boldsymbol{B})$, cytosolic PKD $(\boldsymbol{C}, \boldsymbol{D})$, and cytosolic ERK $(\boldsymbol{E}, \boldsymbol{F})$ in HEK-FLAG-PAR 2 -HA cells. A, $\boldsymbol{C}$, $\boldsymbol{E}$, Time courses. $\boldsymbol{B}$, Area under curve (AUC) for cytosolic CAMP $\left(F_{(2,12)}=26.43,{ }^{* * * *} p=0.00,004\right.$ for $\operatorname{Lgmn} 10 \mathrm{ng} / \mu \mathrm{l}$ compared with vehicle, one-way ANOVA with Tukey's test, $n=5)$. D, AUC for cytosolic DKAR $\left(F_{(2,12)}=69.77,{ }^{* * *} p=2.5 \mathrm{E}-7\right.$ for $\mathrm{Lgmn} 10 \mathrm{ng} / \mu \mathrm{l}$ and ${ }^{*} p=0.0117$ for Lgmn $1 \mathrm{ng} / \mu \mathrm{l}$ compared with vehicle, one-way ANOVA with Tukey's test, $n=5)$. $\boldsymbol{F}$, AUC for cytosolic ERK $\left(F_{(2,12)}=10.99,{ }^{* *} p=0.0015\right.$ for Lgmn $10 \mathrm{ng} / \mu \mathrm{l}$ compared with vehicle, one-way ANOVA with Tukey's test, $\left.n=5\right)$.

(determined by patch clamp). These effects of Lgmn were prevented by a Lgmn inhibitor and absent in neurons from mice lacking $\mathrm{PAR}_{2}$, confirming necessity of $\mathrm{PAR}_{2}$ activation. The nociceptive behavior we measured accords with Lgmn-induced neuronal hypersensitivity. Lgmn induced nociceptive responses in anatomic regions innervated by DRG (paw) and TG (craniofacial) neurons; a Lgmn inhibitor and selective deletion of $\mathrm{PAR}_{2}$ in $\mathrm{Na}_{\mathrm{v}} 1.8$ neurons attenuated nociceptive responses. A Lgmn inhibitor eliminated chronic mechanical and thermal nociception in mice inoculated with OSCC cells.

OSCC patients complain of mechanical-induced and function-induced pain and not spontaneous pain (Connelly and Schmidt, 2004; Kolokythas et al., 2007). Our operant orofacial pain assay and automated device to perform the assay (dolognawmeter) quantifies a behavioral index of mechanical allodynia during gnawing (comparable to chewing in humans). Lgmninduced mechanical allodynia and heat hyperalgesia in OSCC patients might involve $\mathrm{PAR}_{2}$ sensitization of TRPV4 and TRPV1 ion channels, respectively (Grant et al., 2007; Sipe et al., 2008). TRPV4 mediates mechanosensation, while TRPV1 responds to heat and acids (Caterina et al., 1999; Liedtke and Friedman, 2003; Liedtke et al., 2003; Suzuki et al., 2003a,b). TRPV4 and TRPV1 are sensitized by adenylyl cyclase-dependent, PKA-dependent, and $\mathrm{PKC} \varepsilon$-dependent mechanisms, which yield ion channel phosphorylation (Numazaki et al., 2002; Amadesi et al., 2006; Zhao et al., 2019). We showed that Lgmn cleavage of $\mathrm{PAR}_{2}$ activates adenylyl cyclase and cAMP formation; cAMP unleashes catalytic subunits of PKA, which subsequently phosphorylate TRPV channels. We also showed that Lgmn alters rheobase through PKC. Lgmn robustly activates PKD, which likely contributes to $\mathrm{PAR}_{2}$ trafficking from Golgi to plasma membrane (Zhao et al., 2019).

HEK293 cell experiments revealed that Lgmn mobilizes intracellular calcium, stimulates formation of cAMP, and activates PKD and ERK. Selective inhibitors of Lgmn abolished the 
calcium responses; we therefore infer that protease activity is necessary. Lgmn-evoked signals were detected only under mildly acidic conditions, consistent with the acidic $\mathrm{pH}$ optimum of Lgmn. We infer that Lgmn-evoked calcium signaling required cleavage/activation of $\mathrm{PAR}_{2}$ because $\mathrm{PAR}_{2}$ antagonism or deletion and mutation of the cleavage site abolished signals. $\mathrm{PAR}_{1}$ antagonism or deletion had no effect. Further studies are needed to reveal mechanisms by which Lgmn activated $\mathrm{PAR}_{2}$ signals to regulate channel activity and nociception. Trypsin activation of $\mathrm{PAR}_{2}$ involves exposure of a tethered ligand domain; peptides mimicking the tethered ligand activate the receptor (Hollenberg et al., 1996). Lgmn activation does not involve a tethered ligand; a synthetic peptide corresponding to the revealed $\mathrm{N}$ terminus was inactive. Trypsin-activated $\mathrm{PAR}_{2}$ recruits $\beta$-arrestins and then internalizes; Lgmn did not promote $\beta$-arrestin recruitment or receptor endocytosis. Thus, like cathepsin $S$ and elastase (Zhao et al., 2014, 2015), Lgmn activates $\mathrm{PAR}_{2}$ by biased mechanisms to evoke pain.

Our findings are relevant for OSCC patients with pain. While the role of $\mathrm{PAR}_{2}$ in OSCC pain is clear, antagonism of $\mathrm{PAR}_{2}$ as a pain therapy approach is challenging. Access to the $\mathrm{PAR}_{2}$ binding pocket frustrates development of a clinically viable $\mathrm{PAR}_{2}$ antagonist (Goh et al., 2009; Suen et al., 2014; Boitano et al., 2015). Moreover, $\mathrm{PAR}_{2}$ continues to signal following cleavage and endocytosis (Jimenez-Vargas et al., 2018); however, we showed that Lgmn-cleaved $\mathrm{PAR}_{2}$ was not endocytosed. Furthermore, blockade of the Lgmn/PAR 2 axis with a Lgmn inhibitor abrogates OSCC pain in mice. Accordingly, a pain therapy strategy that utilizes blockade of Lgmn is physiologically expedient and holds great clinical potential.

\section{References}

Ahn HS, Foster C, Boykow G, Stamford A, Manna M, Graziano M (2000) Inhibition of cellular action of thrombin by N3-cyclopropyl-7-[[4-(1methylethyl)phenyl]methyl]-7H-pyrrolo[3, 2-f] quinazoline-1,3-diamine (SCH 79797), a nonpeptide thrombin receptor antagonist. Biochem Pharmacol 60:1425-1434

Amadesi S, Cottrell GS, Divino L, Chapman K, Grady EF, Bautista F, Karanjia R, Barajas-Lopez C, Vanner S, Vergnolle N, Bunnett NW (2006) Protease-activated receptor 2 sensitizes TRPV1 by protein kinase Cepsilon- and A-dependent mechanisms in rats and mice. J Physiol 575:555-571.

Amadesi S, Grant AD, Cottrell GS, Vaksman N, Poole DP, Rozengurt E, Bunnett NW (2009) Protein kinase D isoforms are expressed in rat and mouse primary sensory neurons and are activated by agonists of protease-activated receptor 2. J Comp Neurol 516:141-156.

Angelo PF, Lima AR, Alves FM, Blaber SI, Scarisbrick IA, Blaber M, Juliano L, Juliano MA (2006) Substrate specificity of human kallikrein 6: salt and glycosaminoglycan activation effects. J Biol Chem 281:3116-3126.

Böhm SK, Khitin LM, Grady EF, Aponte G, Payan DG, Bunnett NW (1996a) Mechanisms of desensitization and resensitization of proteinase-activated receptor-2. J Biol Chem 271:22003-22016.

Böhm SK, Kong W, Bromme D, Smeekens SP, Anderson DC, Connolly A, Kahn M, Nelken NA, Coughlin SR, Payan DG, Bunnett NW (1996b) Molecular cloning, expression and potential functions of the human proteinase-activated receptor-2. Biochem J 314:1009-1016.

Boitano S, Hoffman J, Flynn AN, Asiedu MN, Tillu DV, Zhang Z, Sherwood CL, Rivas CM, DeFea KA, Vagner J, Price TJ (2015) The novel PAR2 ligand C391 blocks multiple PAR2 signalling pathways in vitro and in vivo. Br J Pharmacol 172:4535-4545.

Caterina MJ, Rosen TA, Tominaga M, Brake AJ, Julius D (1999) A capsaicinreceptor homologue with a high threshold for noxious heat. Nature 398:436-441.

Connelly ST, Schmidt BL (2004) Evaluation of pain in patients with oral squamous cell carcinoma. J Pain 5:505-510.

Corvera CU, Déry O, McConalogue K, Böhm SK, Khitin LM, Caughey GH, Payan DG, Bunnett NW (1997) Mast cell tryptase regulates rat colonic myocytes through proteinase-activated receptor 2. J Clin Invest 100:1383-1393.

Corvera CU, Déry O, McConalogue K, Gamp P, Thoma M, Al-Ani B, Caughey GH, Hollenberg MD, Bunnett NW (1999) Thrombin and mast cell tryptase regulate guinea-pig myenteric neurons through proteinaseactivated receptors-1 and -2. J Physiol 517:741-756.

Coultrap SJ, Sun H, Tenner TE Jr, Machu TK (1999) Competitive antagonism of the mouse 5-hydroxytryptamine 3 receptor by bisindolylmaleimide I, a "selective" protein kinase C inhibitor. J Pharmacol Exp Ther 290:76-82.

Dai Y, Wang S, Tominaga M, Yamamoto S, Fukuoka T, Higashi T, Kobayashi K, Obata K, Yamanaka H, Noguchi K (2007) Sensitization of TRPA1 by PAR2 contributes to the sensation of inflammatory pain. J Clin Invest 117:1979-1987.

Dall E, Brandstetter H (2012) Activation of legumain involves proteolytic and conformational events, resulting in a context- and substrate-dependent activity profile. Acta Crystallogr Sect F Struct Biol Cryst Commun 68:24-31.

Dall E, Brandstetter H (2016) Structure and function of legumain in health and disease. Biochimie 122:126-150.

Dayan D, Salo T, Salo S, Nyberg P, Nurmenniemi S, Costea DE, Vered M (2012) Molecular crosstalk between cancer cells and tumor microenvironment components suggests potential targets for new therapeutic approaches in mobile tongue cancer. Cancer Med 1:128-140.

DeFea KA, Zalevsky J, Thoma MS, Déry O, Mullins RD, Bunnett NW (2000) Beta-arrestin-dependent endocytosis of proteinase-activated receptor 2 is required for intracellular targeting of activated ERK1/2. J Cell Biol 148:1267-1281.

Déry O, Thoma MS, Wong H, Grady EF, Bunnett NW (1999) Trafficking of proteinase-activated receptor- 2 and beta-arrestin- 1 tagged with green fluorescent protein. beta-Arrestin-dependent endocytosis of a proteinase receptor. J Biol Chem 274:18524-18535.

Deseure K, Koek W, Adriaensen H, Colpaert FC (2003) Continuous administration of the 5-hydroxytryptamine1A agonist (3-chloro-4fluoro-phenyl)-[4-fluoro-4-[((5-methyl-pyridin-2-ylmethyl)-amino]-methyl] piperidin-1-yl]-methadone (F 13640) attenuates allodynia-like behavior in a rat model of trigeminal neuropathic pain. J Pharmacol Exp Ther 306:505-514.

DeWire SM, Ahn S, Lefkowitz RJ, Shenoy SK (2007) Beta-arrestins and cell signaling. Annu Rev Physiol 69:483-510.

Dolan JC, Lam DK, Achdjian SH, Schmidt BL (2010) The dolognawmeter: a novel instrument and assay to quantify nociception in rodent models of orofacial pain. J Neurosci Methods 187:207-215.

Edgington LE, Verdoes M, Ortega A, Withana NP, Lee J, Syed S, Bachmann MH, Blum G, Bogyo M (2013) Functional imaging of legumain in cancer using a new quenched activity-based probe. J Am Chem Soc 135:174182.

Edgington-Mitchell LE (2016) Pathophysiological roles of proteases in gastrointestinal disease. Am J Physiol Gastrointest Liver Physiol 310:G234G239.

Edgington-Mitchell LE, Rautela J, Duivenvoorden HM, Jayatilleke KM, van der Linden WA, Verdoes M, Bogyo M, Parker BS (2015) Cysteine cathepsin activity suppresses osteoclastogenesis of myeloid-derived suppressor cells in breast cancer. Oncotarget 6:27008-27022.

Edgington-Mitchell LE, Wartmann T, Fleming AK, Gocheva V, van der Linden WA, Withana NP, Verdoes M, Aurelio L, Edgington-Mitchell D, Lieu T, Parker BS, Graham B, Reinheckel T, Furness JB, Joyce JA, Storz P, Halangk W, Bogyo M, Bunnett NW (2016) Legumain is activated in macrophages during pancreatitis. Am J Physiol Gastrointest Liver Physiol 311:G548-G560.

Farmer LJ (2013) Imidazopyridazines useful as inhibitors of the PAR-2 signaling pathway. U.S. Patent Application WO 2015/048245.

Gillies RJ, Liu Z, Bhujwalla Z (1994) 31P-MRS measurements of extracellular $\mathrm{pH}$ of tumors using 3-aminopropylphosphonate. Am J Physiol 267: C195-C203.

Goh FG, Ng PY, Nilsson M, Kanke T, Plevin R (2009) Dual effect of the novel peptide antagonist K-14585 on proteinase-activated receptor-2-mediated signalling. Br J Pharmacol 158:1695-1704.

Grant AD, Cottrell GS, Amadesi S, Trevisani M, Nicoletti P, Materazzi S, Altier C, Cenac N, Zamponi GW, Bautista-Cruz F, Lopez CB, Joseph EK, Levine JD, Liedtke W, Vanner S, Vergnolle N, Geppetti P, Bunnett NW (2007) Protease-activated receptor 2 sensitizes the transient receptor 
potential vanilloid 4 ion channel to cause mechanical hyperalgesia in mice. J Physiol 578:715-733.

Hachem JP, Crumrine D, Fluhr J, Brown BE, Feingold KR, Elias PM (2003) $\mathrm{pH}$ directly regulates epidermal permeability barrier homeostasis, and stratum corneum integrity/cohesion. J Invest Dermatol 121:345-353.

Hachem JP, Behne M, Aronchik I, Demerjian M, Feingold KR, Elias PM, Mauro TM (2005) Extracellular pH Controls NHE1 expression in epidermis and keratinocytes: implications for barrier repair. J Invest Dermatol 125:790-797.

Hollenberg MD, Saifeddine M, al-Ani B (1996) Proteinase-activated receptor-2 in rat aorta: structural requirements for agonist activity of receptoractivating peptides. Mol Pharmacol 49:229-233.

Jensen DD, Godfrey CB, Niklas C, Canals M, Kocan M, Poole DP, Murphy JE, Alemi F, Cottrell GS, Korbmacher C, Lambert NA, Bunnett NW, Corvera CU (2013) The bile acid receptor TGR5 does not interact with $\beta$-arrestins or traffic to endosomes but transmits sustained signals from plasma membrane rafts. J Biol Chem 288:22942-22960.

Ji RR, Baba H, Brenner GJ, Woolf CJ (1999) Nociceptive-specific activation of ERK in spinal neurons contributes to pain hypersensitivity. Nat Neurosci 2:1114-1119.

Jiang Y, Yau MK, Lim J, Wu KC, Xu W, Suen JY, Fairlie DP (2018) A potent antagonist of protease-activated receptor 2 that inhibits multiple signaling functions in human cancer cells. J Pharmacol Exp Ther 364:246-257.

Jimenez-Vargas NN, Pattison LA, Zhao P, Lieu T, Latorre R, Jensen DD, Castro J, Aurelio L, Le GT, Flynn B, Herenbrink CK, Yeatman HR, Edgington-Mitchell L, Porter CJH, Halls ML, Canals M, Veldhuis NA, Poole DP, McLean P, Hicks GA, et al. (2018) Protease-activated receptor2 in endosomes signals persistent pain of irritable bowel syndrome. Proc Natl Acad Sci USA 115:E7438-E7447.

Kembhavi AA, Buttle DJ, Knight CG, Barrett AJ (1993) The two cysteine endopeptidases of legume seeds: purification and characterization by use of specific fluorometric assays. Arch Biochem Biophys 303:208-213.

Kolokythas A, Connelly ST, Schmidt BL (2007) Validation of the University of California San Francisco oral cancer pain questionnaire. J Pain 8:950953.

Lam DK, Schmidt BL (2010) Serine proteases and protease-activated receptor 2-dependent allodynia: a novel cancer pain pathway. Pain 149:263-272.

Lam DK, Dang D, Zhang J, Dolan JC, Schmidt BL (2012) Novel animal models of acute and chronic cancer pain: a pivotal role for PAR2. J Neurosci 32:14178-14183.

Lee J, Bogyo M (2010) Development of near-infrared fluorophore (NIRF)-labeled activity-based probes for in vivo imaging of legumain. ACS Chem Biol 5:233-243.

Li C, Zhou Y, Liu J, Su X, Qin H, Huang S, Huang X, Zhou N (2019) Potential markers from serum-purified exosomes for detecting oral squamous cell carcinoma metastasis. Cancer Epidemiol Biomarkers Prev 28:1668-1681.

Li N, Liu Q, Su Q, Wei C, Lan B, Wang J, Bao G, Yan F, Yu Y, Peng B, Qiu J, Yan X, Zhang S, Guo F (2013) Effects of legumain as a potential prognostic factor on gastric cancers. Med Oncol 30:621.

Liedtke W, Friedman JM (2003) Abnormal osmotic regulation in trpv4-/mice. Proc Natl Acad Sci USA 100:13698-13703.

Liedtke W, Tobin DM, Bargmann CI, Friedman JM (2003) Mammalian TRPV4 (VR-OAC) directs behavioral responses to osmotic and mechanical stimuli in Caenorhabditis elegans. Proc Natl Acad Sci USA 100 [Suppl 2]:14531-14536.

Lieu T, Savage E, Zhao P, Edgington-Mitchell L, Barlow N, Bron R, Poole DP, McLean P, Lohman RJ, Fairlie DP, Bunnett NW (2016) Antagonism of the proinflammatory and pronociceptive actions of canonical and biased agonists of protease-activated receptor-2. Br J Pharmacol 173:27522765.

Liu Y, Bajjuri KM, Liu C, Sinha SC (2012) Targeting cell surface alpha(v)beta (3) integrin increases therapeutic efficacies of a legumain protease-activated auristatin prodrug. Mol Pharm 9:168-175.

Logozzi M, Capasso C, Di Raimo R, Del Prete S, Mizzoni D, Falchi M, Supuran CT, Fais S (2019) Prostate cancer cells and exosomes in acidic condition show increased carbonic anhydrase IX expression and activity. J Enzyme Inhib Med Chem 34:272-278.

Matthews SP, Werber I, Deussing J, Peters C, Reinheckel T, Watts C (2010) Distinct protease requirements for antigen presentation in vitro and in vivo. J Immunol 184:2423-2431.
Meyer KA, Kammerling EM, Amtman L, Koller M, Hoffman SJ (1948) pH studies of malignant tissues in human beings. Cancer Res 8:513-518.

Mikula KM, Tascón I, Tommila JJ, Iwaï H (2017) Segmental isotopic labeling of a single-domain globular protein without any refolding step by an asparaginyl endopeptidase. FEBS Lett 591:1285-1294.

Murthy R, Xiong H, Nunez R, Cohen AC, Barron B, Szklaruk J, Madoff DC, Gupta S, Wallace MJ, Ahrar K, Hicks ME (2005) Yttrium 90 resin microspheres for the treatment of unresectable colorectal hepatic metastases after failure of multiple chemotherapy regimens: preliminary results. J Vasc Interv Radiol 16:937-945.

Ness KA, Eddie SL, Higgins CA, Templeman A, D’Costa Z, Gaddale KK, Bouzzaoui S, Jordan L, Janssen D, Harrison T, Burkamp F, Young A, Burden R, Scott CJ, Mullan PB, Williams R (2015) Development of a potent and selective cell penetrant Legumain inhibitor. Bioorg Med Chem Lett 25:5642-5645.

Newell K, Franchi A, Pouyssegur J, Tannock I (1993) Studies with glycolysisdeficient cells suggest that production of lactic acid is not the only cause of tumor acidity. Proc Natl Acad Sci USA 90:1127-1131.

Numazaki M, Tominaga T, Toyooka H, Tominaga M (2002) Direct phosphorylation of capsaicin receptor VR1 by protein kinase Cepsilon and identification of two target serine residues. J Biol Chem 277:1337513378

Nystedt S, Emilsson K, Larsson AK, Strömbeck B, Sundelin J (1995) Molecular cloning and functional expression of the gene encoding the human proteinase-activated receptor 2. Eur J Biochem 232:84-89.

Ohlstein EH, Vickery L, Sauermelch C, Willette RN (1990) Vasodilation induced by endothelin: role of EDRF and prostanoids in rat hindquarters. Am J Physiol 259:H1835-H1841.

Ohno Y, Nakashima J, Izumi M, Ohori M, Hashimoto T, Tachibana M (2013) Association of legumain expression pattern with prostate cancer invasiveness and aggressiveness. World J Urol 31:359-364.

Oikonomopoulou K, Hansen KK, Saifeddine M, Tea I, Blaber M, Blaber SI, Scarisbrick I, Andrade-Gordon P, Cottrell GS, Bunnett NW, Diamandis EP, Hollenberg MD (2006) Proteinase-activated receptors, targets for kallikrein signaling. J Biol Chem 281:32095-32112.

Ono K, Ye Y, Viet CT, Dang D, Schmidt BL (2015) TRPV1 expression level in isolectin B4-positive neurons contributes to mouse strain difference in cutaneous thermal nociceptive sensitivity. J Neurophysiol 113:33453355.

Pickering V, Gupta JR, Quang P, Jordan RC, Schmidt BL (2008) Effect of peripheral endothelin-1 concentration on carcinoma-induced pain in mice. Eur J Pain 12:293-300.

Ramachandran R, Mihara K, Mathur M, Rochdi MD, Bouvier M, Defea K, Hollenberg MD (2009) Agonist-biased signaling via proteinase activated receptor-2: differential activation of calcium and mitogen-activated protein kinase pathways. Mol Pharmacol 76:791-801.

Scheff NN, Bhattacharya A, Dowse E, Dang RX, Dolan JC, Wang S, Kim H, Albertson DG, Schmidt BL (2018) Neutrophil-mediated endogenous analgesia contributes to sex differences in oral cancer pain. Front Integr Neurosci 12:52.

Schmidt BL, Pickering V, Liu S, Quang P, Dolan J, Connelly ST, Jordan RC (2007) Peripheral endothelin A receptor antagonism attenuates carcinoma-induced pain. Eur J Pain 11:406-414.

Shields SD, Ahn HS, Yang Y, Han C, Seal RP, Wood JN, Waxman SG, DibHajj SD (2012) Nav1.8 expression is not restricted to nociceptors in mouse peripheral nervous system. Pain 153:2017-2030.

Sipe WE, Brierley SM, Martin CM, Phillis BD, Cruz FB, Grady EF, Liedtke W, Cohen DM, Vanner S, Blackshaw LA, Bunnett NW (2008) Transient receptor potential vanilloid 4 mediates protease activated receptor 2induced sensitization of colonic afferent nerves and visceral hyperalgesia. Am J Physiol Gastrointest Liver Physiol 294:G1288-G1298.

Steinhoff M, Vergnolle N, Young SH, Tognetto M, Amadesi S, Ennes HS, Trevisani M, Hollenberg MD, Wallace JL, Caughey GH, Mitchell SE, Williams LM, Geppetti P, Mayer EA, Bunnett NW (2000) Agonists of proteinase-activated receptor 2 induce inflammation by a neurogenic mechanism. Nat Med 6:151-158.

Suen JY, Barry GD, Lohman RJ, Halili MA, Cotterell AJ, Le GT, Fairlie DP (2012) Modulating human proteinase activated receptor 2 with a novel antagonist (GB88) and agonist (GB110). Br J Pharmacol 165:1413-1423.

Suen JY, Cotterell A, Lohman RJ, Lim J, Han A, Yau MK, Liu L, Cooper MA, Vesey DA, Fairlie DP (2014) Pathway-selective antagonism of proteinase activated receptor 2. Br J Pharmacol 171:4112-4124. 
Suzuki M, Mizuno A, Kodaira K, Imai M (2003a) Impaired pressure sensation in mice lacking TRPV4. J Biol Chem 278:22664-22668.

Suzuki M, Watanabe Y, Oyama Y, Mizuno A, Kusano E, Hirao A, Ookawara S (2003b) Localization of mechanosensitive channel TRPV4 in mouse skin. Neurosci Lett 353:189-192.

Ungefroren H, Witte D, Mihara K, Rauch BH, Henklein P, Jöhren O, Bonni S, Settmacher U, Lehnert H, Hollenberg MD, Kaufmann R, Gieseler F (2017) Transforming growth factor- $\beta 1$ /activin receptor-like kinase 5mediated cell migration is dependent on the protein proteinase-activated receptor 2 but not on proteinase-activated receptor 2-stimulated Gq-calcium signaling. Mol Pharmacol 92:519-532.

van den Beuken-van Everdingen MH, de Rijke JM, Kessels AG, Schouten HC, van Kleef M, Patijn J (2007) Prevalence of pain in patients with cancer: a systematic review of the past 40 years. Ann Oncol 18:1437-1449.

Vasiljeva O, Papazoglou A, Krüger A, Brodoefel H, Korovin M, Deussing J, Augustin N, Nielsen BS, Almholt K, Bogyo M, Peters C, Reinheckel T (2006) Tumor cell-derived and macrophage-derived cathepsin B promotes progression and lung metastasis of mammary cancer. Cancer Res 66:5242-5250.

Vaupel PW, Frinak S, Bicher HI (1981) Heterogeneous oxygen partial pressure and $\mathrm{pH}$ distribution in $\mathrm{C} 3 \mathrm{H}$ mouse mammary adenocarcinoma. Cancer Res 41:2008-2013.

Vergnolle N, Bunnett NW, Sharkey KA, Brussee V, Compton SJ, Grady EF, Cirino G, Gerard N, Basbaum AI, Andrade-Gordon P, Hollenberg MD, Wallace JL (2001) Proteinase-activated receptor-2 and hyperalgesia: a novel pain pathway. Nat Med 7:821-826.

Yamano S, Viet CT, Dang D, Dai J, Hanatani S, Takayama T, Kasai H, Imamura K, Campbell R, Ye Y, Dolan JC, Kwon WM, Schneider SD, Schmidt BL (2017) Ex vivo nonviral gene delivery of $\mu$-opioid receptor to attenuate cancer-induced pain. Pain 158:240-251.

Yao P, Ding Y, Han Z, Mu Y, Hong T, Zhu Y, Li H (2017) Suppression of asparaginyl endopeptidase attenuates breast cancer-induced bone pain through inhibition of neurotrophin receptors. Mol Pain 13:1744806917708127.
Yarwood RE, Imlach WL, Lieu T, Veldhuis NA, Jensen DD, Klein Herenbrink C, Aurelio L, Cai Z, Christie MJ, Poole DP, Porter CJH, McLean P, Hicks GA, Geppetti P, Halls ML, Canals M, Bunnett NW (2017) Endosomal signaling of the receptor for calcitonin gene-related peptide mediates pain transmission. Proc Natl Acad Sci USA 114:1230912314.

Ye Y, Dang D, Zhang J, Viet CT, Lam DK, Dolan JC, Gibbs JL, Schmidt BL (2011) Nerve growth factor links oral cancer progression, pain, and cachexia. Mol Cancer Ther 10:1667-1676.

Ye Y, Bae SS, Viet CT, Troob S, Bernabé D, Schmidt BL (2014a) IB4(+) and TRPV1 $(+)$ sensory neurons mediate pain but not proliferation in a mouse model of squamous cell carcinoma. Behav Brain Funct 10:5.

Ye Y, Ono K, Bernabé DG, Viet CT, Pickering V, Dolan JC, Hardt M, Ford AP, Schmidt BL (2014b) Adenosine triphosphate drives head and neck cancer pain through P2X2/3 heterotrimers. Acta Neuropathol Commun $2: 62$

Zhao P, Lieu T, Barlow N, Metcalf M, Veldhuis NA, Jensen DD, Kocan M, Sostegni S, Haerteis S, Baraznenok V, Henderson I, Lindström E, Guerrero-Alba R, Valdez-Morales EE, Liedtke W, McIntyre P, Vanner SJ, Korbmacher C, Bunnett NW (2014) Cathepsin S causes inflammatory pain via biased agonism of PAR2 and TRPV4. J Biol Chem 289:2721527234.

Zhao P, Lieu T, Barlow N, Sostegni S, Haerteis S, Korbmacher C, Liedtke W, Jimenez-Vargas NN, Vanner SJ, Bunnett NW (2015) Neutrophil elastase activates protease-activated receptor-2 (PAR2) and transient receptor potential vanilloid 4 (TRPV4) to cause inflammation and pain. J Biol Chem 290:13875-13887.

Zhao P, Pattison LA, Jensen DD, Jimenez-Vargas NN, Latorre R, Lieu T, Jaramillo JO, Lopez-Lopez C, Poole DP, Vanner SJ, Schmidt BL, Bunnett NW (2019) Protein kinase D and G $\beta \gamma$ mediate sustained nociceptive signaling by biased agonists of protease-activated receptor-2. J Biol Chem 294:10649-10662 